\title{
The Pulse of Freedom? Bhaskar's Dialectic and Marxism
}

\author{
Sean Creaven
}

\section{Introduction}

Eight years have elapsed since the publication of Roy Bhaskar's Dialectic. The stated aim of this project was extraordinarily ambitious. This was basically threefold. First, the 'dialectical enrichment and deepening of critical realism understood as consisting of transcendental realism as a general theory of science and critical naturalism as a special theory of social science'. Second, 'the development of a general theory of dialectic ... which will ... be capable of sustaining the development of a general metatheory for the social sciences, on the basis of which they will be capable of functioning as agencies of human selfemancipation.' Third, 'the outline of the elements of a totalising critique of western philosophy, in its various (including hitherto dialectical) forms ... [that is] capable ... of casting light on the contemporary crisis of socialism'. ${ }^{1}$ All of this was to be achieved primarily through the 'non-preservative sublation of Hegelian dialectic $^{2}$ and the preservative sublation of Marxian dialectic. Bhaskar's Dialectic thus offered the prospect of providing 'a philosophical basis for Marxian social theory consistent with Marx's own undeveloped methodological insights ${ }^{3}$ and of philosophically under-labouring a genuinely emancipatory socialist political project.

Given the scope of the ambition of Dialectic (in terms of politics and philosophy), and given that it was intended to clarify Bhaskar's relationship to Marxism, drawing up a balance sheet of the respective merits and demerits of the new dialectical critical realism (DCR) system introduced by Bhaskar in Dialectic is long overdue. This is the task of the current undertaking. This will entail addressing two kinds of issues. First, the issue of whether the DCR system of Dialectic overreaches and transcends Bhaskar's earlier critical realism (CR) system, and the adequacy of Bhaskar's dialectical concepts. Second, the issue of the nature of the relationship between Marxism and Bhaskar's dialectic. Here I will consider the following questions. Does Bhaskar's DCR amount to a 'transcendence' or 'outflanking' (albeit sublative) of Marxian dialectic? Is DCR indispensable to Marxism for the formal specification of its dialectics? Or is Bhaskar's dialectic better understood as simply the systematic specification, refinement and development of Marxian dialectic, a legitimate extension and deepening of Marxian dialectic?

\footnotetext{
${ }^{1}$ Bhaskar 1993, p. 2.

${ }^{2}$ Bhaskar 1993, p. xiii.

${ }^{3}$ Bhaskar and Norrie 1998, p. 561.
} 
The broad argument pursued here can be summarised as follows. First, although Bhaskar's DCR system is a qualitative advance on his earlier CR system, and although it undoubtedly offers important insights for Marxism, it neither outflanks nor transcends Marxian dialectic, but is rather dependent on it, and often in unacknowledged ways. Second, despite the considerable merits of Bhaskar's dialectic, its explanatory and critical edge is considerably blunted by a range of conceptual ambiguities, problems and defects, at least some of which are not shared by classical Marxian dialectic.

It is these which problematise any interpretation of Bhaskar's DCR as a 'new beginning' for Marxism. Yet this is not to say that the broader Bhaskarian project of specifying a defensible realist philosophy is not of fundamental relevance to Marxism. Bhaskar's central concepts of stratification and emergence, which undergo further development in his DCR system, do allow of a productive solution to some major dilemmas of Marxist thought (such as the relationship between freedom and necessity, voluntarism and determinism, agency and structure, and base and superstructure), though these concepts were initially developed outside the DCR system.

Third, notwithstanding the limitations of Dialectic, Bhaskar's DCR is a welcome and progressive development of his CR, not least because he rehabilitates dialectical analysis in philosophy and social theory, and to an audience often unfamiliar with and sometimes hostile to dialectics, in a fashion which is broadly consistent with Marxian dialectic. Therefore, a synthesis of these fundamental ontological concepts of CR and DCR with Marxian dialectic offers the prospect of a promising way forward for critical emancipatory theory. For some this is what Bhaskar's Dialectic is all about. Yet I will argue that Bhaskar has not adequately fulfilled this task.

Before dealing with these issues and developing these sorts of arguments, however, it is necessary to briefly consider the substance of Bhaskar's critique of Hegelian dialectic. For Bhaskar's non-preservative sublation of Hegel's philosophy (as he sees it) is precisely the foundation of his own reconstructed dialectic.

\section{Bhaskar's critique of Hegelian dialectic}

For Bhaskar, the principal difficulty of Hegel's logic is its eradication of the dualism of thought and reality, of subject and object, by means of 'a complete and self-consistent idealism', which vindicates 'the identity of being and thought in thought'. ${ }^{4}$ Hegel, says Bhaskar, conceives of dialectic as a 'logical process ... of

\footnotetext{
${ }^{4}$ Bhaskar 1998, p. 579.
} 
reunification of opposites, transcendence of limitations and reconciliation of differences': ${ }^{5}$

From the achieved vantage point of (positive) reason the mutual exclusivity of opposites passes over into the recognition of their reciprocal interdependence (mutual inclusion): they remain inseparable yet distinct moments in a richer, more total conceptual formation (which will in turn generate a new contradiction of its own). It is the constellational identity of understanding and reason within reason which fashions the continually recursively expanding kaleidoscopic tableaux of absolute idealism... Dialectic ... is ... the process by which the various categories, notions or forms of consciousness arise out of each other to inform ever more inclusive totalities until the system of categories, notions or forms as a whole is completed. ${ }^{6}$

Enlightenment is thus a process of negating negation, and it culminates in the 'achieved constellational identity' of subject and object in consciousness, as thought finally grasps the world as rational totality, as part of itself, which exists as rational totality in order to enable philosophical self-consciousness to be achieved. The unification of subject and object is, then, simply the process by which Reason becomes self-conscious. This constitutes the telos of Hegel's system, the historical moment where totality becomes 'constellationally' closed or completed. $^{7}$

For Hegel ... truth is the whole, the whole is a process and this process is reason... Its result is reconciliation to life in (Hegelian) freedom. Error lies is one-sidedness, incompleteness and abstraction. Its symptom is the contradictions it generates and its remedy their incorporation into fuller, richer, more concrete, inclusive, englobing and highly mediated conceptual forms. ${ }^{8}$

Now the chief problem with Hegel's method, argues Bhaskar, is that it rides roughshod over the ontological reality of stratification and emergence, which the 'first wave' of his critical realist philosophy was concerned with demonstrating. In effect, Hegel's dialectic parcels itself out by resorting to 'cognitive triumphalism'.

\footnotetext{
${ }^{5}$ Bhaskar 1998, p. 579.

${ }^{6}$ Bhaskar 1998, p. 581.

${ }^{7}$ By 'constellational closure' Bhaskar does not attribute to Hegel the view that history simply ceases, that change no longer occurs. Rather, his point is that change for Hegel, after constellational identity between subject and object has been realised, is forever bounded by the forms of capitalist modernity. Change is constellationally closed - ie. bound within the limits of the structure or system.

${ }^{8}$ Bhaskar 1998, p. 581.
} 
'Cognitive triumphalism', says Bhaskar, involves postulating the identity of being and consciousness, thought and existence. But this identity is possible only given Hegel's 'anthropomorphic' conception of knowledge (ie. his assumption that the totality of strata are in principle fully knowable), and his imposition of an artificial closure on totality (to allow the possibility of a correspondence of knowledge and reality once the former has 'caught up' with the latter). Bhaskar wishes to show that the realist concepts of stratification and emergence cannot support Hegel's notion of a closed totality, this undermining his identity of subjective and objective dialectics. For Bhaskar, by contrast, '[g]ood totalities are ... open; bad totalities are ... closed ... the exact opposite of Hegel's point of view'.?

But, says Bhaskar, 'the non-identity of subject and object ensures that there is no reason why all being must be conceivable being, let alone why all being must be conceived of already.' The fact that the cosmos is an "'open totality" ensures that there is always the possibility, indeed likelihood, of newly emergent strata (most importantly, the possibility of new social structures brought about by human agency), so that reality is forever incomplete and inherently impossible to grasp fully'. ${ }^{10}$ Bhaskar's critique (whatever the merits of his interpretation of Hegel) thus lends support and real theoretical content to the key term of materialist dialectic: the unity-in-difference of being and consciousness

As Andrew Brown points out, for Bhaskar, because strata are 'equal members of the same hierarchy, [they have] an aspect of unity (dualism or pluralism is rejected)'; at the same time, because 'the strata are not the same as, nor reducible to, one another ... they have an aspect of difference (reductionism is rejected)'. ${ }^{11}$ By contrast, cognitive triumphalism, argues Bhaskar, involves reducing the world to a non-hierarchical flat space with fixed or determinate boundaries and dimensions, calling to a halt the ongoing process of determinate negation in physical and social systems. This denies the existence of 'multiple totalities' and of the openness and incompleteness of each of these, and can lead to the 'epistemic fallacy' of treating questions about knowledge and questions about the world as identical, thereby reducing ontology to epistemology.

Yet Hegel's cognitive triumphalism is logically internally questionable as well as insecure on substantive theoretical grounds, says Bhaskar. For Hegel, 'truth consists in totality and the conformity of an object to its notion.' This being the case, Hegel ought to accept that 'the concept of an open totality must be more true (complete and adequate) than the concept of a closed totality, because it is more comprehensive, englobing and contains the latter as a special case'. ${ }^{12}$ But Hegel's view is exactly the opposite, claims Bhaskar. Thus Bhaskar's attribution to Hegel of a 'principle of identity', interpreted as the view that there must be no discrepancy between thought and its objects, stands in contradiction to the rational

\footnotetext{
${ }^{9}$ Bhaskar 1998, p. 585.

${ }^{10}$ Brown 2000, p. 11.

${ }^{11}$ Brown 2000, p. 8.

${ }^{12}$ Bhaskar 1998, p. 586.
} 
unfolding of Hegel's conceptual dialectic. Logically, the structures of reality have to be grasped as 'open-ended', if Hegel's 'progressivist' conceptualisation of dialectic as the movement towards a richer, fuller, more universal philosophical consciousness is to be upheld.

\section{Bhaskar's dialectic}

Bhaskar's dialectic has a number of fundamental features that are especially worthy of note. First, Bhaskar rejects the 'traditional' (Hegelian?) understanding of dialectic as the linear triadic process of negation (thesis-antithesis-synthesis), though he does not explicitly identify this understanding with Hegel here. Bhaskar wishes to break with the view that dialectic is simply about the 'law' of the interpenetration of opposites in a given structure or system, which leads to their preservative sublation in a higher totality (a new structure or system). Instead Bhaskar argues that 'dialectical processes and configurations are not always sublatory (ie. supersessive), let alone preservative'. ${ }^{13}$

Nor is dialectic necessarily characterised by opposition or antagonism. On the contrary, as often dialectical processes and configurations are characterised by 'mere connection, separation or juxtaposition'. ${ }^{14}$ This means that dialectical consciousness consists of 'the art of thinking the coincidence of distinctions and connections. ${ }^{15}$ As Bhaskar puts it, dialectical mechanisms and configurations are '[a]nything from any relation between differential elements to the absenting of constraints on the absenting of absences, or ills'. ${ }^{16}$ At the most abstract level, then, Bhaskar wishes to grasp dialectic as 'any kind of interplay between differentiated but related elements'. ${ }^{17}$ But, more concretely, he wishes to define dialectic as a specific kind of process or configuration, the logic or dynamic of which is a function of its structure. Dialectic is structure-in-process and process-in-structure by virtue of the interconnections and oppositions which bring about the elaboration or transformation of a given system or totality or of some or more of its elements.

Second, although Bhaskar recognises that Hegel describes reality as a 'differentiated totality', his view is that the idealist and teleological logic of Hegel's dialectic ends up denying this in practice. 'Difference' is subordinated to 'unity' in Hegel's system. Now Bhaskar wishes to reverse this order of priority. As Andrew Brown points out, for Bhaskar, given that each 'stratum is constituted by its own sui generis causal powers (and liabilities), which can be adequately conceptualised in isolation from any concept of the root stratum', it follows that

\footnotetext{
13 Bhaskar 1993, p. 3.

${ }^{14}$ Bhaskar 1993, p. 3.

15 Bhakar 1993, p. 180.

${ }^{16}$ Bhaskar 1993, p. 396.

${ }^{17}$ Bhaskar 1993, pp. 98-9.
} 
'in reality there is nothing present in the emergent stratum connecting it to the root stratum. Because of this ... it is the aspect of difference that requires emphasis within the critical realist ontology'. ${ }^{18}$

Third, despite Bhaskar's powerful - though arguably sometimes misplaced - attack on Hegel's system (which, aside from the polemic against Hegel's cognitive triumphalism, ontological monovalence and attendant theory/practice inconsistency, also rips into Hegel's monism, his 'logicisation of being', his 'mysticism', his 'preservative sublationism', his 'centrism', his 'primal squeeze', and other things besides), ${ }^{19}$ he nonetheless wishes to preserve the 'rational core' of Hegel's dialectic. ${ }^{20}$ This is Hegel's notion that dialectical process is essentially expressive of the logic of negation.

Bhaskar wishes to grasp 'negative dialectics' as the 'absenting of absence', or more specifically 'the absenting of constraints on absenting absences or ills'. ${ }^{21}$ Bhaskar points out that the rational kernel of Hegel's dialectic is its grasp of scientific development and conceptual thought generally as expressive of the logic of negating negativity (or absenting absence on Bhaskar's gloss). But Bhaskar regards both subjective and objective dialectics as being characterised by the absenting of absence. Thus, although Bhaskar distinguishes between conceptual, social and natural dialectical processes (and their various subsets), he nonetheless regards all of these as energised by the logic of absence or negation. Ontologically, the process is synonymous with social and natural geo-history. Epistemologically, the process is synonymous with progress in philosophical and theoretical thought, particularly the logic of scientific discovery. Normativelypractically, the process is precisely 'the axiology of freedom'.

Finally, Bhaskar wishes to both substantiate and radicalise this Hegelian insight. This he does by defining the central or basic dialectical category as 'real determinate absence or non being.'22 'Negativity', for Bhaskar, is thus grasped as 'the linchpin of all dialectics.' He makes the claim that his 'is the only system of dialectical philosophy ... to sustain an adequate account of negativity ... and [therefore] of dialectic itself'. ${ }^{23}$ But this absence or negativity is not simply a property of conceptual thought (or rather its incompleteness), but of the

\footnotetext{
${ }_{19}^{18}$ Brown 2000, p. 9.

19 Thus elsewhere Bhaskar describes Hegel's philosophy as 'atomist, punctualist, extensionalist and individualist, expressivist-holist, blockist, intensionalist and collectivist'. Bhaskar 1993, p. 91. I have to admit that the meaning of most of these 'dialectical' insults escapes me.

${ }^{20}$ This does not imply that Bhaskar does not find much of value in Hegel's philosophy. Aside from endorsing the 'rational kernel' of Hegel's dialectic (the logic of negativity in conceptual thought), Bhaskar points out that Hegel provides 'brilliant diagnoses of real, including nonlogical, dialectical contradictions of civil society which he never sublates'. Bhaskar 1993, p. 64. Bhaskar argues that these elements of Hegel's thought are inconsistent with his teological idealism and cognitive triumphalism.

${ }^{21}$ Bhaskar 1993, p. xiv.

${ }^{22}$ Bhaskar 1993, p. 5.

${ }^{23}$ Bhaskar 1993, p. xiv.
} 
ontological status of reality itself. Bhaskar is against what he calls 'ontological monovalence', which he defines as a 'purely positive, complementing a purely actual, notion of reality'. ${ }^{24}$ For Bhaskar the necessity of absence or non-being ('negative dialectics') is given by the open-ended nature of reality. Without absence or negativity there can be no dialectic, he argues. If negativity or absence were entirely cancelled out by positive being, the dialectic would cease, and with it change, development, evolution, emergence, leaving us with Hegel's 'constellationally' closed totality ('endism').

At first sight, charging the founder of modern dialectics with ontological monovalence is logically indefensible. But, if one accepts Bhaskar's interpretation of Hegel's philosophy, his claim can be substantiated. On this view, Hegel's negation of the negation eventually parcels itself out with the eventual historical reunification of subject and object. Hegel's 'master concept which drives his dialectics on (for the most part teleologically) - lack or absence ... - is not preserved within his system ... Positivity and self(-identity), the very characteristics of understanding, are always restored at the end of reason'. ${ }^{25}$ So Hegel's 'absenting of the notion of absence ... checks genuine change, betrays the positivity of absolute idealism, and renders Hegel vulnerable to ... ontological monovalence'. ${ }^{26}$ For Hegel, there was history, but there is no longer in capitalist modernity. Positive being reigns supreme.

Overall, argues Bhaskar, 'the chief result of ontological monovalence in mainstream philosophy is to erase the contingency of existential questions and to despatialise and detemporalise being, ${ }^{27}$ Thus, Bhaskar would claim for Dialectic that it marks a decisive break with the dominant tradition in philosophy, commencing with Parmenides, which treats reality as entirely positive being. Bhaskar identifies ontological monovalence as the key philosophical error that Dialectic is concerned to combat, just as the epistemic fallacy was the key target of his earlier work in its pre-dialectical CR mode.

Now, for Bhaskar "negativity is a condition of positive being'. ${ }^{28}$ Thus absence or non-being is ontologically fundamental or prior to presence or being:

'If a totally positive material object world - a packed world without absences - is impossible, there is no a priori reason to exclude the opposite - namely a total void, literally nothing. Negativity is constitutively essential to positivity, but the converse does not follow... Non-being is a condition of possibility of being. No non-being is a sufficient condition of possibility of

\footnotetext{
${ }^{24}$ Bhaskar 1993, pp. 4-5.

${ }^{25}$ Bhaskar 1993, p. 27.

${ }^{26}$ Bhaskar 1993, p. 95.

${ }^{27}$ Bhaskar 1993, p. 7.

${ }^{28}$ Bhaskar 1993, p. 47.
} 
being. But there is no logical incoherence in totally no being... if there was an originating Absolute, nothing would be its being or form. ${ }^{29}$

Indeed, Bhaskar even goes so far as to say that non-being or absence is an ocean, whereas being and presence are merely the ripple on its surface. Real determinate absence or negativity energises the struggle for presence or positivity. ${ }^{30}$ This is the essence of dialectic.

Bhaskar here also usefully distinguishes between three types of negation "real negation, "transformative negation" and "radical negation". ${ }^{31}$ Of these "the most basic is real negation', which denotes a wide range of things, including an 'absence from consciousness (eg. the unknown, the tacit, the unconscious)', or 'an entity, property or attribute (eg. the spaces in a text) in some determinate spacetime region', or 'a process of mediating, distancing or absenting'.$^{32}$ Bhaskar sees real negation as the motor of dialectic, of which the other modes of negation are subsets. 'Transformative negation refers to the transformation of some thing, property or state of affairs. Such a transformation may be essential or inessential, total or partial, endogenously and/or exogenously effected.' This is a particular kind of real negation, though not all real negations are transformative. Such processes 'involve the cessation or absenting of a pre-existing entity or state'. These seem to fit the bill in accounting for processes of stratification and emergence generally, though here it seems to me that the determinate negations are inherently sublative. Finally, radical negation 'involves the auto-subversion, transformation or overcoming of a being or condition', ${ }^{34}$ and is a special case of transformative negation, and therefore of real negation. This is negation as selftransformation. This mode of negation appears to fit the bill in accounting for processes of internally generated or 'organic' development or evolution, such as the dialectic of life or consciousness.

Bhaskar's account of negativity provides the basis of his analysis of contradiction. Bhaskar argues that the 'concept of contradiction may be used as a metaphor (like that of force in physics) for any kind of dissonance, strain or tension'. ${ }^{35}$ Bhaskar identifies several different types of contradiction. The nodal meaning of contradiction 'specifies a situation which permits the satisfaction of one end or more generally result only at the expense of another; that is, a bind or constraint.' The concept of 'internal contradiction' refers to a 'double bind or selfconstraint (which may be multiplied to form a knot). In this case a system, agent or structure, $\mathrm{S}$, is blocked from performing with one system, rule or principle, $\mathrm{R}$,

\footnotetext{
${ }^{29}$ Bhaskar 1993, p. 46.

${ }^{30}$ Bhaskar 1993, p. 5.

${ }^{31}$ Bhaskar 1993, p. 5.

32 Bhaskar 1993, p. 5.

${ }^{33}$ Bhaskar 1993, p. 6.

${ }^{34}$ Bhaskar 1993, p. 6.

${ }^{35}$ Bhaskar 1993, p. 56.
} 
because it is performing with another, R'; or, a course of action, T, generates a countervailing, inhibiting, T'. R' and T' are radically negating of $R$ and $T$ respectively'. ${ }^{36}$ Bhaskar sees such internal contradictions as essential to the possibility of emergent entities and of change as a self-implementing process inherent to its bearer.

The concept of 'external contradiction' refers us to 'the laws and constraints of nature (such as the speed of light), to be established by the mere fact of determinate spatio-temporal being, ${ }^{37}$ In terms of society, the concept may perhaps also usefully refer to the inter-relations that exist between structures of a given social system or social formation, insofar as these are not relations of mutual presupposition (ie. internal and necessary connections between elements of a totality), but insofar as these entail mutual incompatibilities or strains between elements of the total system. The concept of 'formal logical contradiction' refers to a 'type of internal contradiction, whose consequences for the subject, unless the terms are redescribed and/or the discursive domain is expanded, ... is axiological indeterminacy ${ }^{38}$ - ie. the lack of rational grounds for action.

The concept of dialectical contradiction is also a species of internal contradiction, though of a different kind. This 'may best be introduced as a species of the more general category of dialectical connections' ${ }^{39}$ Dialectical connections require us to think in terms of 'entity relationism'. ${ }^{40}$ These 'are connections between entities or aspects of a totality such that they are in principle distinct but inseparable'. ${ }^{41}$ These are relations of existential presupposition, of intra-action rather than interaction, involving the permeation of co-constituents within a relationship or configurational whole. But dialectical contradictions, although possessing all of these features of dialectical connections, 'are also opposed, in the sense that (at least) one of their aspects negates (at least) one of the other's, or their common ground or the whole, and perhaps vice versa, so that they are tendentially mutually exclusive, and potentially or actually tendentially transformative'. ${ }^{42}$ Dialectical contradictions may be radical or transformative, depending on whether these negate the source of the existential incompatibility between elements of the totality or the common ground of the totality itself, or whether these accommodate or inform processes of dynamic restructuring which can be contained within a given totality or which do not sublate its common ground.

\footnotetext{
${ }^{36}$ Bhaskar 1993, p. 56.

${ }^{37}$ Bhaskar 1993, p. 56.

${ }^{38}$ Bhaskar 1993, p. 56.

${ }^{39}$ Bhaskar 1993, p. 58.

${ }^{40}$ Bhaskar 1993, p. 125.

${ }^{41}$ Bhaskar 1993, p. 58.

${ }^{42}$ Bhaskar 1993, p. 58.
} 


\section{Bhaskar and Marxian dialectic}

The moment of transition of Bhaskar's Dialectic from critique of Hegelian dialectic to articulation of a system of dialectical critical realism begins with Bhaskar's account of Marxian dialectic. Bhaskar endorses much of Marx's critique of Hegel, this constituting the starting point of his own critique of Hegel and 'dialectical enrichment and deepening of critical realism'. ${ }^{43}$ Bhaskar says that in Hegel contradictions are resolved or cancelled by being 'retrospectively redescribed as moments of a transcending totality', ${ }^{44}$ therefore being resolved in thought. Ultimately objective dialectical contradictions are dissolved into subjective logical contradictions, which are then transcended by virtue of progress in conceptual thought (the 'logicisation of being'). This means that 'Hegelian dialectic ... is never simultaneously dialectical and contradictory' (Ibid.).

By contrast, 'the materialist dialectic is', ${ }^{45}$ says Bhaskar. Materialist 'dialectical contradictions ... such as those identified by Marx in his systematic dialectics', describe (dialectical), but do not suffer from (logical), contradictions ... The practical resolution of the contradiction here is the non-preservative transformative negation of the ground' of the internally relational but 'tendentially mutually exclusive' totality of which they are a part, ${ }^{46}$ this requiring the intervention of practical human agency in the social and material worlds. Marx's critique of Hegel thus opens up the possibility of a 'materialist diffraction of dialectic', ie. the articulation of a pluriform dialectic, unfolding at various levels of conceptual thought and objective reality. This being the case, Bhaskar's 'four levels' of dialectical critical realism are 'perhaps best seen as four dimensions of this diffracted dialectic, each with its own distinctive concepts, scientific applications, and philosophical problems'. ${ }^{47}$

But Bhaskar's plural dialectic, though starting from Marx's own diffraction of dialectic, extends far beyond it. Before examining the conceptual structure of DCR, and in order to better grasp its relationship with Marxism, is it is necessary to briefly consider the basic nature of Marxian dialectic. Materialist dialectic, as developed by Marx, Engels, Lenin and Trotsky, is based upon certain fundamental principles of Hegel's dialectic, which are defensible. Yet this classical Marxism does claim at the same time transform the manner of the application of these Hegelian concepts, in such a way that it correct to speak of an 'inversion' of Hegel's dialectic. The 'rational core' of Hegel's dialectic, for classical Marxism, is precisely the fundamental principles of 'totality', 'mediation', 'change' and 'contradiction', which constitute the theoretical foundations of the Hegelian

\footnotetext{
${ }^{43}$ Bhaskar 1993, p. 2.

${ }^{44}$ Bhaskar 1993, p. 62.

45 Bhaskar 1993, p. 62.

${ }^{46}$ Bhaskar 1993, pp. 60-1, 58.

${ }^{47}$ Callinicos 1994, p. 9.
} 
system. ${ }^{48}$ These can be seen at work in the methodological framework that informs all of the theoretical positions and specific explanatory hypotheses of Marx and Engels' body of work, and are also manifest in Lenin and Trotsky's philosophical commentaries on the nature of Hegelian and Marxian dialectic.

Consider a single example: Marx's 'logic of capital'. Explanatory theory and method follow here a definite logic. First, capitalist society is grasped as a unitary system, a 'rich totality of many determinations and relations'. ${ }^{49}$ The structural unity-in-difference of capitalism is given by a specific configuration of forces and relations and production. Second, Marx wishes to understand capitalism as a system in constant development and change, as following 'laws of motion', which are integral to its functioning as a particular mode of production, by virtue of the specific way the unity of particular forces and relations of production is accomplished.

Thus Marx takes the classical economists to task for universalising bourgeois society, for treating the economic categories of capitalism as applicable to all previous societies, where these are regarded as undeveloped, and to all possible futures. For Marx, by contrast, '[e]conomic categories are only the abstractions of the social relations of production', ${ }^{50}$ those of a historically specific and transitory form of society.

Finally, Marx grasps the relationship between totality and change in capitalist society as mediated by the concept of 'contradiction'. Capitalism is theorised as a 'unity of opposites', whose 'law of motion' is a function of the conflictual relationship between forces and relations of production (ie. the competition of 'many capitals' in the marketplace, and the tendency of the relations of production to fetter the development of the forces of production beyond a certain point), and between opposed social classes (ie. between the propertied bourgeoisie and the propertyless proletariat) over control of authoritative and allocative resources and the production process.

The unity of capitalism exists because production and consumption, forces and relations of production, capital and labour, presuppose one another. There cannot be consumption without production, social labour without appropriate tools and technology, capital without wage labour, or vice versa. These are dialectical connections in Bhaskar's sense. The contradictions of capitalism are derived from the manner in which the unity of economic elements - forces and relations of production, production and consumption, etc.- is accomplished in this specific mode of production. Capital and wage-labour, for example, constitute an opposition as well as a unity. This is because, although neither can exist in the absence of the other (capital is simply objectified labour; wage-labour is simply the means of capital accumulation), neither can they co-exist harmoniously. In

\footnotetext{
${ }^{48}$ Rees 1998 impressively develops this argument.

${ }^{49}$ Marx 1973, p. 100.

${ }^{50}$ Marx and Engels 1975b, p. 165.
} 
part, this is due to the fact that the relationship between them is asymmetrical (wage labour exists only to service capital; and capital is structurally parasitic on wage-labour). But, in equal measure, this is due to the fact labour power as a commodity 'is not detachable from the body/person of the wage labourer, so attempts by capital to use the "commodity" it has bought will inevitably bring into conflict with the person to whom this "commodity" remains attached. ${ }^{51}$ These are internal transformative dialectical contradictions in Bhaskar's sense.

Engels made the point that 'three laws' of dialectic - the 'unity of opposites', the 'transformation of quantity into quality', and the 'negation of the negation' - can usefully be distilled from Hegel's work. ${ }^{52}$ For Hegel, these are ways of specifying how dialectical processes unfold, though these concepts are not the only acceptable way of doing so, because not every dialectical process will fit the pattern they outline. Now there can little doubt that the classical Marxists adopt these basic analytical tools of Hegel's dialectic, though again without assuming these capture or exhaust every dialectical process at work in the world. ${ }^{53}$ But it is important to understand that they do so, not as a mechanical or deterministic formula adopted prior to research, into which real world processes have to be fitted, but rather as elements of an explanatory framework, based on the findings or knowledge of empirical science, which is also of practical efficacy in interpreting and organising research data. ${ }^{54}$

For Marx, this is one sense in which the materialist dialectic can be legitimately said to invert the Hegelian. On this kind of interpretation, Hegel's dialectic is basically a conceptually-driven dialectic, in which contradictions either arise from the limitations of human consciousness as it struggles to apprehend the world, or from the drive of 'world spirit' to force itself past the constraints of 'objective spirit' (society and culture). In this process contradictions are eventually dissolved as thought finally appropriates the world as its own mirror, as identical to Spirit, or energises the practical struggles which hammers the objective world into correspondence with Reason or Spirit. This ensures that Hegel's dialectical concepts are cast adrift from the disciplines of empirical testing and the possibility of refutation by scientific knowledge, since the starting point of Hegelian analysis is always the Idea, rather than the material world from which ideas are ultimately derived. So, although Hegel did illustrate dialectical processes with the latest scientific findings, this tended to be done in a fairly ad hoc way. Instead, Hegel's dialectic arguably unfolds at the height of philosophical abstraction, presenting

\footnotetext{
${ }^{51}$ I am grateful to an anonymous reviewer of this article for this insight.

${ }^{52}$ Engels 1982, p. 6.

${ }^{53}$ For example, Marx uses 'the negation of the negation' concept to illuminate the transition from petty commodity production to capitalism in Capital. Marx 1976, pp. 713-15. More generally, Marx's sketch of the transition from feudalism to capitalism and from capitalism to socialism in Capital can be legitimately interpreted as drawing on these concepts.

${ }^{54}$ Rees 1998, pp. 114-18.
} 
properties or objects of the material world as more or less developed forms of the general abstract concepts that are applied to them. ${ }^{55}$

Thus, argues Marx, Hegel's dialectic does reveal the contradictions that exist in categories and conceptual thought. The classic example of this would be the 'unequal and opposed ... shapes of consciousness' of rulers and ruled, articulated in Hegel's philosophy of history. ${ }^{56}$ Here the metaphysical identity of thought and being ensures that change is understood in terms of a dynamic of social consciousness rather than in terms of a dynamic of social relations.

This can be illustrated by briefly examining Hegel's master-slave dialectic. ${ }^{57}$ At the beginning of the process, the lord is the dominant power. The lord 'is the independent consciousness whose essential nature is to be for itself'. ${ }^{58}$ The servant is compelled, under fear of death, to labour in the service of the lord. So the servant 'is the dependent consciousness whose essential nature is to live ... for another'. ${ }^{59}$ The servant is mired in 'servile thinking', ie. the servant lives in fear of the lord, which is necessary for subsequent historical progress from 'barbarism' to 'civilisation'. But the servant's labour on the object mediates the relationship between oppressor and oppressed, and this transforms the servant's consciousness. By working on the material world in providing the lord with subsistence, the servant comes to realise his or her own independence from the world of objects (as producer of the things appropriated by another). Roles come to be grasped differently by the servant: the lord is actually dependent on the servant and falsely believes that (s)he is the independent power. 'Through his rediscovery of himself by himself, the bondsman realizes that it is precisely in his work wherein he seemed to have only an alienated existence that he acquires a mind of his own'. ${ }^{60}$

Arguably, then, Hegel elides contradictions in social consciousness and contradictions in material social structure (contradictions in thought and wider social and material reality are seen as identical). This undermines the distinction between subjective and objective dialectics in Hegel's philosophy and leads him into idealism. The point is well made by John Rees:

[T] he dialectic of lordship and bondage confirms the idealist nature of Hegel's analysis. Only the bondsman's consciousness has been transformed, not his real relation to the lord. There has been a revolution in thought but no revolution in social relations. The Hegelian dialectic begins with the dominant consciousness of the lord and the subservient consciousness of the

\footnotetext{
${ }^{55}$ Marx 1975, pp. 98-9; Marx and Engels 1975a, pp. 57-8.

${ }^{56}$ Hegel 1977, p. 117.

${ }^{57}$ My account here draws heavily on John Rees's excellent discussion of Hegel's master-slave dialectic. Rees 1998, pp. 37-9.

${ }^{58}$ Rees 1998, pp. 37-9.

${ }^{59}$ Rees 1998, pp. 37-9.

${ }^{60}$ Rees 1998, p. 119.
} 
bondsman and ends with the transformed consciousness of the bondsman. The 'real world of existence' and work is necessary, but only features as the mediating middle term. ${ }^{61}$

So Hegel's dialectic can be represented thus: consciousness (servile thinking) $\rightarrow$ labour on the material world $\rightarrow$ transformed consciousness (independent thinking). Each dialectical sequence begins and ends with consciousness. In practice, Hegel's treatment of social consciousness and social relations as identical means that each phase of his dialectic implies a reconciliation of thought and objective reality, rather than a transformed social and material reality.

Hegel himself did not understand this. This is because he did not see that material social structures always bound and limit forms of social consciousness, and that practical social struggles transform social consciousness only by virtue of transforming the social and material worlds. On the contrary, for Hegel, social consciousness is transformed not by virtue of a transformation of social conditions (the servant achieves 'independent thinking' in the absence of the overthrow of the social relations of slavery). This is the sense in which Hegel's dialectic can be reasonably interpreted as driven by ideas: once a higher stage of Reason is attained, this ultimately 'rules' the practical struggles in the material world that bring about the reshaping of social institutions and objective culture to fit the dialectical movement of Reason. For Hegel, ascending states of consciousness, as these are translated into deeds, remodel the world, culminating in the emergence of free wage labour under capitalism, this constituting the terminus of his dialectic of history.

In contrast to this idealist method, Marx and Engels insisted that their 'point of departure' is the material world, the object and instrument of human labour, from which all forms of consciousness are derived. ${ }^{62}$ Concepts are the product of real conditions, yet are distinct from these conditions, shaped by existential contradictions. They then have to be abstracted from their objects, and subjected to rational procedures of scientific testing, then reapplied to their objects in the form of more sophisticated concepts, if they are to apprehend the nature of real world processes or structures. Further, because contradictions exist outside consciousness, are independent of consciousness, and indeed often account for the contradictions in consciousness, existing in their own right in the structures of society and nature, it follows that objective reality and subjective reality cannot be elided. There is a unity between subjective and objective dialectics, not a simple identity. ${ }^{63}$

\footnotetext{
${ }^{61}$ Rees 1998, p. 39.

${ }^{62}$ Marx and Engels 1970.

${ }^{63}$ This distinction between the Marxian and Hegelian dialectic was drawn out by Lenin (1972) and theorised more precisely by Trotsky (1986).
} 
For Marx and Engels, processes in nature unfold independently of thought and culture via real dialectical connections and oppositions, whereas contradictions in social consciousness are 'bounded' by and expressive of contradictions of material social relations. This situation can be contrasted with Hegel, for whom contradictions of social consciousness express and bound contradictions of real life. For Marx and Engels, the material struggles of social agents, as these are over-determined by structural social relations, bring about social transformations. Again, this can be contrasted with Hegel, for whom practical struggles in the material world act as the tool of Reason or Spirit to bring about social transformations. ${ }^{64}$

For classical Marxism, then, consciousness is not the first and last term of the dialectic of human history, as it arguably was in Hegel, but is its mediating middle term. And this middle term is understood not as abstract Reason, but as conscious collaborative labour in the sensuous world, in the service of human needs and wants. ${ }^{65}$ Thus Marx's dialectic can be represented as follows: material reality (social relations and physical conditions) $\rightarrow$ social consciousness $\rightarrow$ transformative social agency (constitutive labour and class struggle), leading to transformed social relations and social consciousness.

This understanding allows us to grasp the manner in which the classical Marxists apply Hegel's 'three laws' of the dialectic. In Hegel these are commonly interpreted as unfolding as a simple concept begets a more refined concept, which contains and transcends the simpler one, and so on, until the Idea is evolved into self-consciousness of the Absolute (the common rational structure of thought and the material world which Hegel understands as Absolute Spirit). In Hegel, furthermore, the historical process by which Spirit discovers or even constructs the world as its own creation is normally seen as essentially teleological, since the self-reconciliation of Spirit at the final stage of the dialectic is immanent in its beginning, the goal to which history gravitates, since this unfolds by virtue of logical necessity, as would a sequence of self-generating concepts. For classical Marxism, by contrast with this interpretation of Hegel's logic, neither the transformation of quantity into quality, nor the negation of the negation, can be interpreted as teleological laws of necessity, whether in social or natural systems.

Of course, making the assertion that classical Marxism is a fundamentally anti-teleological and non-deterministic body of social theory would be considered by many critical realists and dialectical critical realists as flying in the face of established academic knowledge. Yet those who assert as much often fail to distinguish the classical Marxist current which links together the theoretical practice of Marx, Engels, Lenin, Trotsky, Lukacs, Gramsci, Luxemburg and a

64 '[S]pirit intervenes in the way the world is ruled. This is the infinite tool. - then there are bayonets, cannon, bodies. But ... neither bayonets, nor money, nor this trick or that, are the ruler ... They are necessary like the cogs and wheels of a clock, but their soul is time and spirit that subordinates matter to its laws'. Cited in Rees 1998, p. 31.

${ }^{65}$ Rees 1998, pp. 69-74. 
handful of more contemporary authors located in the labour movement (which is opposed to fatalism and positivism), from the broader tradition of so-called 'orthodox' Marxism, which includes the whole of Second International and Stalinised Marxism, irrespective of its (often positivistic and fatalistic) conceptual and methodological content. ${ }^{66}$ Moreover, it is a lamentable fact that this kind of understanding is grossly misinformed, shaped as it has been by the exigencies of Cold War politics (and now the spectre of a repentant communism and socialism in a world reputed to be 'beyond left and right') ${ }^{67}$ and their knock-on effects in academia, which includes a failure to approach central Marxian texts in the spirit of immanent critique, and worse still often evidence a lack of acquaintance with primary sources.

But it is worth pointing out that the textual evidence in Marx and Engels' oeuvre as a whole supporting the 'orthodox' interpretation is extremely flimsy. By and large, most of this is concentrated in the 'early works', prior to Marx and Engel's first statement of historical materialism in The German Ideology, before their break with Hegel's idealist philosophy of history. Now it seems a little foolish to criticise Marx for his conceptual and methodological failings before he had a chance to formulate the distinctive conceptual and methodological tools of Marxism. Yet even here in the 'early works' there is rather more in the way of textual data which undermines the orthodox critique. For example, in The Philosophical and Economic Manuscripts of 1844, which is often singled out as especially prone to teleology by the critics (and not without some justification), Marx insists that communism is not preordained by historical laws. "Communism as such is not the goal of human development', but is rather 'the "actual" phase necessary for the next stage in the process of human emancipation', ie. the necessary stage of history if alienation is to be overcome. ${ }^{68}$

If this is not clear enough, in The German Ideology, Marx and Engels are utterly unambiguous that historical materialism has nothing in common with teleological historicism:

History is nothing but the succession of the separate generations, each of which exploits the capital funds, the productive forces handed down to it by all preceding generations, and thus, on the one hand, continues the traditional activity in completely changed circumstances and, on the other hand, modifies the old circumstances with a completely changed activity. This can be speculatively distorted so that later history is made the goal of earlier history ... Thereby history receives its own special aims and becomes 'a person ranking with other persons' ... while what is designated

\footnotetext{
${ }^{66}$ Molyneux 1985.

${ }^{67}$ Giddens 1997.

${ }^{68}$ Marx 1959, p. 101.
} 
with the words 'destiny', 'goal', 'germ', or 'idea' of earlier history is nothing more than an abstraction formed from later history. ${ }^{69}$

So the fundamental problem with the view that Marxian dialectic is essentially teleological and 'historicist' (in Karl Popper's sense of the term) is that it is compelled to exaggerate the significance of the existing empirical evidence in support of this position in Marx and Engels' post-1845 writings to make any kind of case at all. Since passages which can be interpreted in an overly 'deterministic' and 'fatalistic' manner have such a marginal presence in Marx and Engels' mature works, amounting to no more than a few passages in a voluminous output spanning thousands of pages of text, it becomes necessary to over-inflate their conceptual weight and explanatory significance to the point of absurdity. But, as I have shown at length elsewhere, even the marginal 'deterministic' aspects of Marx and Engels' mature output can often be interpreted legitimately in a more charitable light (once placed in their textual context), since these tend to function simply as rhetorical embellishments to the unfolding of theoretical concepts, cutting against the grain of the analytical problematic in which they are situated. ${ }^{70}$

An oft-quoted example of this is Marx's brief sketch of the 'expropriation of the expropriators' in the third volume of Capital. ${ }^{71}$ This can be interpreted in a deterministic light, of course. But it can equally be read innocently as simply a statement of the necessary conjuncture of objective economic circumstances required to allow the replacement of capitalism with socialism.

To offer a more obvious example, even Marx's famous claim that 'the Asiatic, ancient, feudal and modern bourgeois modes of production can be designated as epochs marking progress in the economic development of society ${ }^{, 72}$ 'should not necessarily be interpreted as a rigid stages theory of social evolution. Rather it can legitimately be understood as a broad historical sketch of successive economic modes that have presided over a cumulative development of humanity's material productive forces'. ${ }^{73}$ This latter interpretation is supported by Marx's own critique of vulgar Marxists, who are taken to task for subsuming history 'under one great natural law' and thus interpreting 'my historical sketch of the genesis of capitalism in western Europe as [an] ... historico-philosophic theory of the general path every people is fated to tread, whatever the historical circumstances in which it finds itself'. ${ }^{74}$

It is also important to note that often the most 'deterministic' passages (of those which can be labelled as deterministic) are to be found in the 'propagandist' (overtly political) rather than mature 'scientific' (sociological and philosophical)

\footnotetext{
${ }^{69}$ Marx and Engels 1970, pp. 57-8.

${ }^{70}$ Creaven 2000b, pp. 7-11.

${ }^{71}$ Marx 1967, p. 763.

${ }^{72}$ Marx 1970, p. 21.

${ }^{73}$ Creaven 2000b, p. 12.

${ }^{74}$ Marx 1934, p. 42.
} 
texts. Yet it should be obvious for contingent political reasons (ie. 'rallying the troops') that these are more prone to speak of the 'historical inevitability' of capitalist downfall and proletarian revolution. The obvious example of this, of course, is the famous 'gravediggers' comment in The Communist Manifesto. ${ }^{75}$

However, irrespective of the value of engaging in a more critical analysis of those Marxian passages that are superficially read as supporting the orthodox critique, it is certain that set against this flimsy and ambiguous evidence of Marxian 'teleologism' and 'positivism' (the positing of historical laws leading to necessary results) is a mountain of textual data and dense conceptual analysis supporting the opposite conclusions. ${ }^{76}$ Thus anti-Marxist critique has long been characterised by the tedious and dishonest practice of scouring Marxian texts for evidence of 'original sin', yanking these 'sins' out of context, and disregarding practically everything substantial that Marx and Engels ever wrote.

I conclude that it is plain silly to attribute any determinate meaning to Marx and Engels' writings as a whole on the basis of isolated passages from a wide range of texts, for good or for ill. Instead I concur with the opinion that these should always be analysed in terms of the conceptual and methodological structure of which they are a part, and considered in terms of their internal consistency with this structure. But, this having been done, the orthodox critique collapses.

Now this interpretation of the dialectic as radically anti-positivist and nonteleological follows from its 'inversion'. That is to say, it follows its transformation from an idealist to a materialist dialectic. For transformative change is now grasped as the collision of social or physical oppositions, without the certainty that a specific resultant or fixed end-state must follow from initial causes or conditions, in advance of the developmental process itself, as would the conclusion of a problem in logic from its initial premises.

As Trotsky puts it: 'Human society has not developed in accordance with a prearranged plan, but empirically, in the course of a long, complicated and contradictory struggle' ${ }^{77}$ This is equally true of physical and social systems. In both cases, the process of the transformation of quantity into quality, ie. the development of structural forms by means of internal and external contradictions and dialectical connections, does not necessarily resolve itself in the negation of the negation (the successive transcendence of lower by higher systems which nonetheless preserve in a modified form elements or properties of the lower).

Now a number of points should be made about the nature of this materialist dialectic. First, I have already shown that it is not 'endist', 'stageist', 'teleological' or 'historicist'. Second, it is anti-reductionist and anti-monist. That is to say, it is pluriform. This is obviously true of historical materialism. ${ }^{78}$ Nor is this any less

\footnotetext{
${ }^{75}$ Marx and Engels 1967, pp. 93-4.

${ }^{76}$ Creaven 2000b, pp. 11-21.

77 Trotsky 1986, p. 90.

${ }^{78}$ The 1859 Preface of Marx's A Contribution to the Critique of Political Economy, for example, manifestly does not speak of relations of mono-causal determination between base and
} 
true of dialectical materialism more generally. Here objective and subjective dialectics are unified but distinct properties of being; and objective dialectical processes and configurations do not constitute a uniform substance, but unfold relatively autonomously at a variety of different levels, in accordance with the distinctive relational properties of their objects or structures. Thus: the dialectic of capitalist modernity involves multiple configurations and contradictions, ${ }^{79}$ the dialectic of society is irreducible to the dialectic of life; the dialectic of life is irreducible to the dialectic of inorganic matter. ${ }^{80}$ Third, it derives enormous explanatory power from a precise, flexible, yet remarkably uncomplicated configuration of dialectical categories. Simplicity (as far as is possible in dialectical analysis!) is combined with excellent explanatory reach and circumnavigation of the fundamental errors that Bhaskar would attribute to Hegelian dialectic (including ontological monovalence, cognitive triumphalism, the epistemic fallacy, teleological determinism, etc.).

These are especially important points to bear in mind as we consider the efficacy of Bhaskar's radicalisation/ transformation/overreach of materialist dialectic. What is added to Marxian philosophy by Bhaskar's highly complex DCR system that it previously lacked? And does the analytical and theoretical pay-off of Bhaskar's DCR, in terms of the benefits its elaborate proliferation of dialectics provide for the social researcher, render it philosophically indispensable to Marxian social theory and emancipatory socialist politics? This is the claim Bhaskar would make for Dialectic. Before addressing this issue, however, it is necessary to grasp how Bhaskar's diffraction of dialectic articulates at the distinct levels of his DCR system.

\section{The four levels of dialectical critical realism}

Bhaskar constructs his dialectical critical realism on the basis of his critique of Hegel's dialectic of identity, negativity and totality. These Hegelian concepts are replaced with his own reworked dialectical concepts of non-identity, negativity, totality and transformative agency. These are mapped onto the 'four levels' of dialectical critical realism. The 'first moment' (1M) basically corresponds to the key concepts of critical realism (stratification, emergence, the non-identity of thought and being, systemic openness, etc.). The 'second edge' (2E) 'is the abode of absence - and, most generally, negativity'. ${ }^{81}$ This entails the remodelling of $1 \mathrm{M}$

\footnotetext{
superstructure or between forces and relations of production, but instead speaks the language of 'correspondence', 'conditioning', rootedness and structural interdependence (Marx, 1970: 20-1) all of which is consistent with a critical realist reading of social processes. Yet this is a favourite target of those who find Marxian sociology guilty of reductionism and monism.

${ }^{79}$ Marx 1973, 1976.

${ }^{80}$ Creaven 2001, pp. 131-54; Rees 1998, pp. 61-125; Sayers 1996.

${ }^{81}$ Bhaskar 1998, p. 644.
} 
concepts 'in the light of dialectical categories such as negativity, negation, becoming, contradiction, process, development and decline, mediation and reciprocity'. ${ }^{82}$ Bhaskar argues that this 'dialectical moment' is necessary to impart dynamism and movement to the relatively static or synchronic concepts of critical realism and to situate processes of change spatially and temporally. This is the 'reassertion of the geo-historicity of being, of tense and place as irreducible and spatio-temporality as real, of the tri-unity of space, time and causality in tensed spatializing process, of emergent, divergent, possibly convergent, causally efficacious spatio-temporalities and rhythmics, of the constitutive presence of the past and outside'. ${ }^{83}$

The 'third level' (3L) corresponds to 'totality' and 'totalising motifs' ${ }^{84}$ The concept of totality denotes 'intra-actively changing embedded ensembles, constituted by their geo-histories ... and their contexts, in open potentially disjointed process'. ${ }^{85}$ And the 'internal and intrinsic connectedness of phenomena deduced from the dialecticisation of $1 \mathrm{M}$ at $2 \mathrm{E}$ reveals the implicit need for totalising motifs which can theorise totality ... and constellationality' ${ }^{86}$ This gives rise to the 'fourth dimension' (4D): 'the zone of transformative agency,' 87 'the unity of theory and practice in practice ${ }^{88}$ This is the process of human practical engagement in the world, in society and nature, which also mediates the poles of consciousness and being, bringing thought into a 'lived relation' with the world, thereby transcending (though without harmonising) the abstract polarities represented by subject and object. Here Bhaskar discusses the range of erroneous interpretations of this 'zone' (physicalism, idealism, dualism, reification, fetishism, commodification), the classical errors of social theory, and the conceptual means of their resolution, which hinges on 'emergent powers materialism' at the level of subject and the dialectic of structure and agency at the level of society.

The interface between (3L) and (4D) can also be interpreted as the 'moment' of 'dialectical critical naturalism', the analysis and theorisation of human society as unity-in-difference, and maps on to Bhaskar's famous 'transformational model of agency'. This is dialectical realism as sociology, politics and ethics. 'Social life, qua totality, is constituted by four dialectically interdependent planes: of material transactions with nature, inter-personal action, social relations, and intra-subjectivity'. ${ }^{89}$ This is the 'social cube', a complex articulation of ensembles of structure-practice-subject in process. Here 'we have

\footnotetext{
${ }^{82}$ Bhaskar and Norrie 1998, p. 562.

${ }^{83}$ Bhaskar 1998, p. 645.

${ }^{84}$ Bhaskar 1993, pp. 8-9.

${ }^{85}$ Bhaskar 1993, p. 126.

${ }^{86}$ Bhaskar and Norrie 1998, p. 563.

${ }^{87}$ Bhaskar 1998, p. 646

${ }^{88}$ Bhaskar 1993, p. 9.

${ }^{89}$ Bhaskar and Norrie 1998, p. 566.
} 
dialectics of unity and diversity, of intrinsic and extrinsic, of part and whole, of centrification and peripheralization, within partial totalities in complex and dislocated open process, substantively under the configuration of global commodification'. ${ }^{90}$

This 'transformational model of social activity avoids the twin errors of reification and voluntarism in a dislocated duality of structure and agency, while the relational conception of social life evades the pitfalls of individualism and collectivism alike'. ${ }^{11}$ By duality (or 'hiatus-in-the duality' as he calls it) Bhaskar means 'the combination of existential interdependence ... and essential ... distinction'. ${ }^{92}$ Like society and nature, human subjects are grasped as stratified and relational entities, not as 'fixed and abstractable from their environment', but 'as 'existentially constituted by their rhythmics or geo-histories and the totality of their relations with other things'. ${ }^{93}$

At this level too the concept of 'power2' relations is central to the analysis. These are defined as 'generalised master-slave type relationships'. ${ }^{94}$ That is, social relations which govern the distribution of material goods, political and military authority, and cultural status (eg. stratification by class, gender and ethnicity). Power2 relations are those which enable human and social agents to defend their sectoral advantages by prevailing 'against either ... the covert wishes and/or ... the real interests of others (grounded in their concrete singularities) ${ }^{95}$ These are to be distinguished from 'Power1' relations, which refer instead simply to the 'transformative capacity' of human agency. ${ }^{96}$ Bhaskar also introduces his politicomoral theory here, in which 'concrete singularity' (the free flourishing of each) 'is the relational condition of concrete universality' (the free flourishing of all). This is understood as 'an immanent and tendential possibility ... necessitated by structural conditions ... [though] held in check by global discursively moralised power2 relations'. ${ }^{97}$

Bhaskar argues that dialectic at this level is 'the logic of freedom'. ${ }^{98}$ This is because dialectic imparts 'a certain, if highly contingent, directionality to geohistory, presaging a society in which the free flourishing of each is the condition for the free flourishing of all'. ${ }^{99}$ This is a progressive tendential movement of humanity towards 'eudaimonia' or universal emancipation. How does this work? The starting point is Bhaskar's definition of dialectic as the process of 'absenting

\footnotetext{
${ }^{90}$ Bhaskar 1998, p. 645.

${ }^{91}$ Bhaskar 1998, p. 659.

92 Bhaskar 1993, p. 115.

${ }^{93}$ Bhaskar 1993, p. 62.

${ }^{94}$ Bhaskar and Norrie 1998, p. 566.

${ }^{95}$ Bhaskar 1993, p. 153.

${ }^{96}$ Bhaskar 1993, p. 60.

${ }^{97}$ Bhaskar 1993, p. 202.

${ }^{98}$ Bhaskar 1993, p. 374.

${ }^{99}$ Bhaskar 1998, p. 646.
} 
absence.' The next step is Bhaskar's argument that 'any ill can be seen as a constraint and any constraint as the absence of a freedom' ${ }^{100}$ From this it follows that dialectic entails 'absenting most notably of constraints on desires, wants, needs and interests' ${ }^{101}$ At its simplest, then, dialectic is powered by the interface of absence and desire, since 'absence is paradigmatically a condition for desire', on the grounds that desire presupposes lack. ${ }^{102}$

Now, for Bhaskar, humanity is bestowed with the 'inner urge' to struggle against lack 'that flows universally from the logic of elemental ... need, want', and this is manifested 'wherever power 2 relations hold sway'. ${ }^{103}$ This is because power2 relations function to negate the needs of most human beings (whether basic survival needs or those defined by wider cultural horizons), giving rise to a desire for freedom from 'absenting ills'. It is this process that offers the tendential possibility of moving 'from primal scream to universal human emancipation'. ${ }^{104}$ Since 'every absence can be seen as a constraint, this goal of human autonomy can be regarded as implicit in the infant's primal scream'. ${ }^{105}$ This is because the unfolding dialectic of absenting absence on freedom (as agents struggle against successive forms of power2 relations), in tandem with expanding cultural definitions of needs and wants constructed in part through this struggle, gives rise to a logic of more inclusive, englobing definitions of and aspirations towards freedom.

These four 'moments' or 'levels' of dialectical critical realism are moments of its own progressive dialecticisation. 'At the beginning of this new dialectic, there is non-identity - at the end, open, unfinished totality', ${ }^{106}$ along with the unityin-difference of consciousness and being. This dialectical movement is regarded by Bhaskar as the antithesis of Hegel's dialectic, where non-identity of consciousness and being is eventually transformed into its opposite.

\section{The balance sheet}

This concludes by account of the conceptual 'nuts and bolts' of Bhaskar's DCR system and its philosophical underpinnings. I will now address the issue of the adequacy of Bhaskar's Dialectic, of its relationship to Marxian dialectic, and thus its overall status in contemporary radical philosophy and social theory. First I will consider the strengths of DCR. Then I will consider its areas of weakness. The claim of DCR to stand as 'new beginning' for dialectical analysis and of providing

\footnotetext{
${ }^{100}$ Bhaskar 1993, p. 182.

101 Bhaskar 1993, p. 175.

102 Bhaskar 1993, p. 242.

${ }^{103}$ Bhaskar 1993, p. 299.

${ }^{104}$ Bhaskar 1993, p. 180.

105 Bhaskar 1993, p. 264.

${ }^{106}$ Bhaskar 1993, p. 3.
} 
Marxism with the formal specification of its dialectics will be considered in the light of my critique.

\section{1) Strengths and advantages}

The great power of Bhaskar's Dialectic is that it does succeed in a number of important tasks it sets itself. First, it succeeds in strengthening the anti-reductionist credentials of critical realism. The understanding of reality as comprised of multiple totalities, in constant movement and change, is a powerful ontological barrier to anti-realism and cognitive triumphalism. Thus the critique of the epistemic fallacy is give a new slant and is considerably enriched. Second, Bhaskar's DCR does demonstrate that the essence of dialectic (at least when applied to cognition, life and society) is the absenting of absence, and in so doing articulates an effective critique of ontological monovalence.

The ingenuity of Bhaskar's argument for treating absence as real, and as key to at least a particular class of dialectic, is that it establishes its point not by inference from perceptual criteria (I know from the fact that Pierre has been present in the café in the past that he is now absent from the café), or from causal criteria (absence as pure negativity must by definition lack causal efficacy), but rather on the grounds that it is simply impossible to conceive of change other than in terms of negativity. 'All causal determination, and hence change, is transformative negation or absenting'. ${ }^{107}$ Third, and in large measure because 'negativity wins' (though as we shall see only up to a point), ${ }^{108}$ Bhaskar's dialectic does reveal the relatively static nature of critical realist concepts and breathe movement and life into them.

Fourth, ontologically, Dialectic does present good arguments as to why theory cannot afford to abstract from space, time and the process of change, and offers the promise of a thoroughgoing historicization of stratification and emergence; and it does invest in these processes spatial and temporal context. Fifth, conceptually, a great deal of the theoretical and analytical content is interesting and challenging, particularly I would say at the levels of (3L) and (4D). Here Bhaskar does successfully argue the relevance of his reworked dialectical concepts of totality and negation and mediation to theorising the relational stratified self (as an 'open ended' construct of multi-layered geo-historical and socio-cultural processes) and the transformational model of social activity, of the interface between them, and of the dialectical interpenetration of consciousness and reality through practical constitutive human agency.

\footnotetext{
${ }^{107}$ Bhaskar 1993, p. 44.

108 As I intend to demonstrate, there are nonetheless profound problems with Bhaskar's 'negative dialectics'.
} 
Certainly, the remodelling of the transformational model of social activity as the 'social cube' seems to me to draw out the multi-dimensional texture and open-ended dynamism of social being. The abstract model of structure and subject of The Possibility of Naturalism and Reclaiming Reality is refashioned as a 'rich totality of many determinations and relations'. This is a parts-whole, unity-indiversity, process-in-product, product-in-process mode of analysis, involving the interpenetration of subject, social practices and structural properties, in concretely situated processes of geo-historical development, powered by the dialectical interface between power1 and power2 relations. A broadly progressive directional logic of social development, and with it a tendential impulse towards universal human freedom, is advanced, which I fully endorse. ${ }^{109}$ This is powered by the dialectic of absenting absence (in both ideal interests and practical interests), which seems consistent with the tendential structural impulse towards eudaimonia that Bhaskar proposes.

Sixth, epistemologically, Bhaskar is right to see dialectic as the 'great loosener'. ${ }^{110}$ Here he has done Marxism a great service by decisively rebutting the influential criticism 'which claims that the notion of dialectical contradictions in reality is incompatible with ... formal logic, coherent discourse, scientific practice or materialism.' As Bhaskar rightly points out, '[t]his is not so', for real contradictions 'may be straightforwardly consistently described and explained [and] only if logical ... contradictions are committed, as distinct from described, that the norm of non-contradiction is infringed' (Bhaskar, 1998: 619). Epistemologically too, it does seem useful to grasp dynamism in conceptual ideas (whether these are philosophical or scientific or commonsense in nature) in terms of the 'absenting of absence', as both Hegel and Bhaskar recommend.

Finally, as social ontology and analytical method, Bhaskar's dialectic is broadly consistent with Marxian social theory. Bhaskar's dialectic is based foursquare on the categorical rejection of what he sees as Hegel's idealism. The dialectic he outlines is a property of the structures of material and social reality, and of the interplay of these with human consciousness, as this is mediated by practical human agency. Dialectic is not simply the autobiography of Reason, as it strides in a linear fashion along the path towards absolute self-knowledge. Contradictions are an objective property of the real, and these are not to be conflated with contradictions in thought or social consciousness, and nor treated as illusions sustained by the imperfections of rational knowledge. Bhaskar's dialectic is materialist dialectic, in the Marxian sense.

Nonetheless, Bhaskar's dialectical critical realism is not without ambiguities, difficulties and substantial problems. I will address the ambiguities and lesser difficulties first, before then considering the more substantial problems.

109 This is in fact an extremely unpopular idea in contemporary philosophy and social theory. However, it is a defensible and plausible one, as I have tried to show elsewhere. Creaven 2000b. ${ }^{110}$ Bhaskar 1993, p. 44. 


\section{2) Ambiguities, difficulties, etc.}

First, there is the question of the extent to which Bhaskar's 'second wave' of realism is indispensable for Marxism, in order to provide it with the formal specification of its dialectics. Despite the brilliance of some of his individual insights and arguments, such is the high level of philosophical abstraction of Bhaskar's Dialectic, and the bewildering array of unfamiliar concepts, positions, tropes, motifs, etc. it contains (many of which are not adequately theorised or argued), it is uncertain to what extent it has genuine practical utility in terms of furnishing social analysis with methodological or theoretical guidance, or underlabouring a genuinely emancipatory political project, such as it claims to represent. Much of it seems simply superfluous (though much of it obviously isn't) to the task of deploying dialectic effectively and incisively in social research or analysis. ${ }^{111}$

This certainly could not be said to be a weakness of the work of the best of the classical Marxists. Here philosophy and social theory was always disciplined by its 'lived relation' with class struggles and the international labour movement, and hence by the litmus test of political practice. ${ }^{112}$ Although Marx himself did not find the time to submit his own dialectical method to systematic analysis, and did not theorise its points of contact with and departure from the Hegelian dialectic, his social theory is nonetheless an object lesson in applied dialectics. Certainly, it has yet to be surpassed by anything produced within critical realism.

I have pointed out that Marx's dialectic has the virtue of incisiveness and simplicity. It is as complex and comprehensive as it needs to be, no more. The same is true of the best work of the leading theoreticians of classical Marxism especially Engels, but also Lenin, Trotsky, Lukacs and Gramsci, and a host of lesser figures. It is instructive that even today the bulk of the more interesting and innovative work in dialectical social theory is far more influenced by Marxism

\footnotetext{
111 For example, Bhaskar's distinction between epistemological and meta-epistemological dialectics, and his concept of relational dialectics, are unnecessary complications of his typology of different modes of dialectic, which advance his case not one iota.

${ }^{112}$ I suppose it could be objected to my argument that this comparison is unfair, because Bhaskar is first and foremost a philosopher, not a sociologist or political activist. This would have some merit if Bhaskar himself did not see his project as directly supportive of emancipatory politics and social science, which he obviously does. But the classical Marxists were simultaneously philosophers, social theorists and political activists because they recognised that philosophy 'left to its own devices' was prone to abstractionism and scholasticism, just as a politics uninformed by critical social theory and philosophy was narrowly empiricist and instrumentalist. The task was to unify practice and theory in practice as practice.
} 
than Bhaskar's dialectical critical realism. ${ }^{113}$ Engels' dialectical materialism, though much maligned and misunderstood by philosophers and social scientists, has had and continues to have a significant impact on the thinking of a number of distinguished natural scientists, ${ }^{114}$ whereas the impact of Bhaskar's alternative outside a narrow academic circle of professional philosophers and social analysts remains negligible. Indeed, even within the camp of critical realism, only a minority have read Dialectic, and even fewer profess to understand it.

Part of the problem is that the book is appallingly written. As Alex Callinicos points out:

Even as sympathetic a critic as Andrew Collier, who calls Bhaskar's work 'the most exciting development in Anglophone philosophy in this halfcentury', admits that his recent writings have been characterised by a 'tendency to condense complex thought into brief formulae ... combined with a large crop of unfamiliar expressions, acronyms and semi-formalised arguments (not to speak of typographic errors and sometimes obscure syntax)'. All of this and more is true of Dialectic, where neologisms and idiosyncratic uses of familiar terms proliferate until they form what verges at times on a private language. Arguments are illustrated by figures whose frequency and complexity obscure rather than instruct. And all too often Bhaskar's prose becomes clogged by what seems the irresistible need to say everything, to add to some specific assertion references to connected considerations and qualifications until the original point is in danger of being lost... Perhaps this is a danger of all dialectical thinking ... But the danger of trying to say everything is that one ends up saying nothing. ${ }^{115}$

The theoreticism of Bhaskar's Dialectic problematise its claim to underlabour the social sciences or provide an emancipatory critique of either capitalism or 'power2 relations' more generally. It appears (often wilfully) inaccessible to all but the tiniest academic elite, and therefore has nothing to say to the billions who urgently require the 'eudaimonistic society' of which it speaks. This is a shame, because Bhaskar's dialectic is the pulse of freedom. Today those who wish to

\footnotetext{
${ }^{113}$ See especially: Arthur 1986; Murray 1988; Rose et al. 1984; Sayers 1996, 1998; Smith 1990, 1993a, 1993b, 2000.

114 Such as John Haldane (physics), Richard Lewontin and Richard Levins (evolutionary biology), Steven Rose (micro-biology), and Ilya Prigogine (thermodynamics). Lewontin and Levins dedicated their book The Dialectical Biologist to Engels, "who got it wrong a lot of the time but who got it right when it counted.' Haldane, surveying the crisis of physics in the 1940s, observed that 'it is astonishing how Engels anticipated the progress of science in the sixty years since he wrote ... Had Engels' methods of thinking been more familiar, the transformation of our ideas on physics during the last thirty years would have been smoother ... Had these books been known to my contemporaries, it was clear that we should have found it easier to accept relativity and quantum theory' (quoted in Sheehan 1993, p. 319).

115 Callinicos 1994, p. 15.
} 
struggle against globalised 'master-slave type social relations' are more likely to draw their inspiration from the new theoreticians of the anti-capitalist movement ${ }^{116}$ than from Bhaskar. This weakness is particularly lamentable given that Bhaskar's reason for writing Dialectic was explicitly political. Thus, for him, socialism is undone because the required 'unity of explanatory critical social theory and emancipatory axiology' has yet to be achieved. 'This is the ultimate absence this book aims to repair'. ${ }^{11}$

However, there is more to explaining the book's uncertain status and limited appeal than its difficult prose. ${ }^{118}$ More seriously, despite a wealth of condensed analysis, and many original and intriguing insights on the nature of dialectic, and despite its comprehensive (though sometimes misplaced) critique of Hegel, too many of the arguments it contains are simply perfunctory or under-theorised, either excessively condensed or extremely brief, in the latter case often little more than scattered jottings. Overall, then, there is an unfortunate tendency to present arguments which are simply lacking in supporting arguments or illustrations. For example, Bhaskar's treatment of the way in which communication presupposes the possibility of human liberation, his demonstration of the ontological primacy of non-being over being, his positive argument against the denial of intransitivity, his argument against Leibniz's principle of non-contradiction in being as well as thought, and against Kant's notion of unitary time, and attempts more generally to demonstrate complex arguments with resort to cursory 'transcendental proofs', all of these fall into these sorts of category.

Sometimes the over-compressed and sketchy character of Bhaskar's analysis raises more questions than it answers. This is especially apparent at the level of his dialectical critical naturalism. Here there are a number of difficulties and ambiguities. First, when addressing the role of structural properties in social systems, there is uncertainty over whether Bhaskar sees these as indispensable to every intentional act of human agency or whether he thinks "natural interaction can supply the necessary and sufficient conditions for intentionality'. ${ }^{119}$ Second, it is also unclear whether Bhaskar sees social structures as existing materially only by virtue of the social agency and concepts which reproduce them or whether these structures are to a certain extent autonomous of and efficacious apart from the social activities and concepts of those subject to their influence or governance.

\footnotetext{
${ }^{116}$ Bourdieu 1998; Danaher and Burbach 2000; George 1994; Klein 1990.

${ }^{117}$ Bhaskar 1993, p. 203.

118 It should be pointed out that a large part of the blame for this 'uncertain status' and 'limited appeal' of Dialectic cannot be laid at Bhaskar's door. Dialectical philosophy, because it is necessarily a challenge to static commonsense and a movement beyond formal logic, is inevitably complex and difficult up to a point. Often the accusation of 'bad writing' directed against Bhaskar by critical realists functions as an excuse not to engage with DCR, to disregard the genuinely challenging and radical aspects of his dialectical reworking of CR categories.

119 Archer 1995, p. 138.
} 
Bhaskar's description of the relationship between structure and agency as duality is suggestive that he favours the former answer in both cases. This impression is reinforced by his claim that the analysis of the interrelationship between structure and interaction in social systems requires not analytical dualism (the investigation of the interconnections between ontologically distinct realities) but 'perspectival shifts' from one 'side' or 'dimension' of a unitary though internally differentiated whole to another (either agency-within-structure, or structure-within-agency). Certainly, this interpretation is not decisively rebutted in his earlier work, ${ }^{120}$ despite his claim that:

People and society are not related dialectically. They do not constitute two moments of the same process. Rather they refer to radically different things. ${ }^{121}$

This is because Bhaskar also argues that social structures 'only exist in virtue of the activities they govern ... and cannot be identified independently of them' and that 'they do not exist independently of the conceptions that the agents have of what they are doing in their activities'. ${ }^{122}$ This seems to be suggestive of a close affinity between Bhaskar's transformational model of social action and Giddens' structuration theory, the latter of which endorses a 'simultaneity model' of the subject-society connection, according to which structural properties and self-identity are simply 'two sides' of the same coin of ongoing social practices. ${ }^{123}$

If so, however, Bhaskar's model is inadequate. The capacity of individuals to act intentionally and rationally is a function of subject - object interactions generally (mediated by practical interests), rather than simply of social interaction and enculturation. ${ }^{124}$ Structural properties (eg. distributions of property and cultural capital) often persist in the absence of agency that would reproduce them, and despite the concerted efforts of collective social action to remove or ameliorate them. This is because they are the emergent properties of the 'dead generations' and confront the living as pre-structured distributions relatively independent of and resistant to their will. ${ }^{125}$

More seriously still, there simply isn't enough in the way of startling new insights into the nature and application of materialist dialectic to justify the 'under-labouring' status as provider of a new philosophical foundation for Marxian social theory and the social sciences generally some would claim for it (and which Bhaskar himself hints at). Three examples will have to suffice.

120 Bhaskar 1989a, pp. 25-6, 174.

${ }^{121}$ Bhaskar 1989b, p. 76.

${ }^{122}$ Bhaskar 1989b, p. 78.

${ }^{123}$ Giddens 1979, 1984.

${ }^{124}$ Archer 2000, pp. 121-53.

${ }^{125}$ Archer 1995, pp. 143-5. 
First, we have seen already that Bhaskar deems Hegel's dialectic inadequate, because Hegel's cognitive triumphalism ensures that totality for him 'is constellationally closed ... an achieved identity', ${ }^{126}$ meaning that the entirety of being is in principle conceivable or knowable. Bhaskar is right to reject this absolutist conception of totality (though whether this critique of Hegel hits the mark is another issue). He points out that new 'base' strata may yet be discovered and that higher strata will undoubtedly emerge, so the totality is never complete or conceivable in its entirety. Yet Engels also rejects the fantastic notion of a complete or closed totality, and for the same reason, because reality for him is a combinatory of open systems in continual motion and change, meaning that knowledge can only approximate to reality without ever exhausting or mirroring it. As Engels puts it: 'From the moment we accept the theory of natural evolution all our concepts ... correspond only approximately to reality. Otherwise there would be no change. On the day when concepts and reality completely coincide ... development comes to an end'. ${ }^{127}$

Second, Bhaskar's observation that dialectical logic cannot simply replace conventional scientific methods or formal logic, but must 'build ... on the later, overreaching but not transcending it, while the latter is at a loss without the former, ${ }^{128}$ is an interesting and defensible argument. Without subjecting theory and practice to 'dialectical overreach', the result is invariably TINA ('there is no alternative' syndrome), the fabrication of 'internally contradictory, more or less systemic, efficacious ... ensembles ... displaying duplicity, equivocation, extreme plasticity ... and rational indeterminacy'. ${ }^{129}$ But, again, this insight does not seem radically different from Trotsky's own view of the appropriate relationship between dialectical method, science and logic. Trotsky argued that formal logic was adequate within certain limits, but became lost in insoluble contradictions when addressing 'more complicated and drawn out processes', ${ }^{130}$ this often forcing the theorist to complement formal logic with arbitrary and external empirical modifications that often contradicted or broke the chain of logical concepts. The solution was a systematic interrogation and integration of abstract logic and empirical science by and through dialectical reasoning. ${ }^{131}$ Trotsky pointed out that this does 'not replace concrete scientific analysis'. Instead it 'directs this analysis along the correct road'. ${ }^{132}$

Third, Bhaskar contrasts Hegelian dialectic to Marxian dialectic, the latter of which is rightly neither treated neither as idealist nor teleological. Bhaskar argues that Marx replaces Hegel's concept of the 'identity of opposites' with the

\footnotetext{
${ }^{126}$ Bhaskar 1998, p. 585.

${ }^{127}$ Engels 1975, p. 459.

${ }^{128}$ Bhaskar 1998, p. 565.

${ }^{129}$ Bhaskar 1993, p. 117.

${ }^{130}$ Trotsky 1973a, p. 49.

${ }^{131}$ Trotsky, 1973b, pp. 400-1.

132 Trotsky 1973a, p. 52.
} 
concept of the 'unity of opposites', since this is necessary to head off the danger of either a materialist or idealist regress. As Bhaskar puts it: 'One might be tempted to contrast here the Kantian independence, Hegelian identity and Marxian unity of opposites ...Marx's dialectical contradictions cannot be said to constitute an identity, but at most a grounded unity, of opposites ... Marx's concern is with the dialectical explanation and practical transformation of capitalism, not with the transfigurative redescription of, and reconciliation to ... the existing state of affairs ....' 133

Bhaskar is right about Marx, of course. Marx applies his reworked concept of the 'unity of opposites' to great effect in his analysis of the logic of capital. For example, in his discussion of the classical liberal political economy of John Stuart Mill, Marx argues: 'Where the economic relation - and therefore the categories expressing it - include contradictions, opposites, and likewise the unity of opposites, he emphasises the aspect of the unity of the contradictions and denies the contradictions. He transforms the unity of opposites into the direct identity of opposites'. ${ }^{134}$ But the same point is a commonplace within the wider classical Marxist tradition, which Bhaskar does not acknowledge, giving the impression that his interpretation is a novel one.

Engels, too, seems to prefer this formulation to the 'identity of opposites', referring to the 'unity of thought and being' and the 'unity of nature and mind'. ${ }^{135}$ I have outlined elsewhere how his dialectic of nature negates in practice the idea that subjective and objective dialectics constitute a unitary substance or logic. ${ }^{136}$ Lenin remarked in his Philosophical Notebooks that Marxists should replace the concept of the 'identity of knowing and being' with the concept of the 'unity of knowing and being'. ${ }^{137}$ And Trotsky built his own reconstructed dialectic around this insight of Lenin's.

This, for example, is what he had to say about the matter in his Philosophical Notebooks:

According to Hegel being and thinking are identical (absolute idealism). Materialism does not adopt this identity - it premises being to thought ... The identity of being and thinking ...signifies the identity of subjective and objective logic, their ultimate congruence. Materialism accepts this correspondence of the subjective and the objective, their unity, but not their identity; in other words it does not liberate matter from its materiality, in order to keep only the logical framework of regularity, of which scientific thought (consciousness) is the expression. ${ }^{138}$

\footnotetext{
${ }^{133}$ Bhaskar 1993, p. 61.

${ }^{134}$ Marx 1971, p. 87, cited in Callinicos 1998, p. 97.

${ }^{135}$ Engels 1982, p. 496.

${ }^{136}$ Creaven 2000a, pp. 32-40.

${ }^{137}$ Lenin, cited in Rees 1998, p. 274.

${ }^{138}$ Trotsky 1986, p. 77, cited in Rees 1994, p. 121.
} 
Of course, whether all of this is interpreted as a problem for Bhaskar's enterprise depends on how one defines the purpose of his project in Dialectic. If Bhaskar intended his contribution as an systematic enrichment or development of Marxian dialectic, rather than as a dialectical reworking of Marxism, or as specifying a realist alternative to or supercession of materialist dialectic, then in this case the difficulties reduce to mere ambiguities as to the status of its relationship with Marxism. At times Bhaskar does seem to identify his role as systematically developing and enriching Marx's ideas - hence his oft-quoted reference to Marx as 'the comet of critical realism.' But elsewhere his grandiose claim for Dialectic that it provides the only adequate account of dialectic cuts against this interpretation. Since it is uncertain what kind of status more generally Bhaskar wishes to attribute to his DCR system in relation to Marxian dialectic, the misgivings I have raised appear noteworthy.

Certainly, the points of contact between Bhaskar's realist dialectics and the materialist dialectics of many leading figures of classical Marxism (as highlighted above) are not generally acknowledged by Bhaskar, this giving the impression that they are seen by him as novel to his own system. Further, despite a generally positive appraisal of Engels' 'three laws' of ontological dialectic, Bhaskar is generally dismissive of dialectical materialism. ${ }^{139}$ Since Bhaskar would claim for DCR the role of philosophically under-labouring the social sciences, and of sublating all previous dialectical philosophy, ${ }^{140}$ this does appear to hint at a rather more ambitious project than simply the systematic elaboration or justification of Marx's materialist dialectic. After all, though methodologically undeveloped, Marx does articulate philosophical foundations of his own for historical materialism, and these have undergone elaboration at the hands of other leading figures of classical Marxism, notably Engels and Trotsky. Yet Bhaskar does not identify his project as contributing to the development of this tradition of materialist philosophy (Lenin and Trotsky are not discussed at all, nor the contemporary left Darwinians, who have developed and applied Engels' ontological dialectic in the biological sciences).

\footnotetext{
${ }^{139}$ Hence Bhaskar refers to the 'simple reflection theory of dialectical materialism' (Bhaskar 1993, p. 217), 'the poverty of most materialist dialectical philosophy' (Bhaskar 1993, p. 300), the 'empiricism' of diamat (Bhaskar 1993, p. 352), and to the 'unhappy consciousness of the split between the objectivist processual empiricism of dialectical materialism and the characteristically subjectivist totalising idealism of western Marxism' (Bhaskar 1993, p. 363). Bhaskar does not distinguish between the mechanical materialism of 'orthodox' diamat and the progressive ontological dialectics of the classical Marxist tradition (which did not suffer from these defects), a line of descent from Engels, through to Lenin and Trotsky, on to Ilyenkov, and finally to more contemporary thinkers in the Trotskyist political current and in major branches of contemporary science. This makes his ontological dialectic appear more revolutionary than in fact it is.

${ }^{140}$ Bhaskar 1993, p. 301.
} 
In any case, whatever Bhaskar's intentions, it is legitimate to observe that much of the real value of Dialectic is not that it revolutionises or transcends or outflanks the Marxian dialectic, or that it develops a radically new critique of Hegelian dialectic. Indeed, much of Bhaskar's critique of Hegel is unoriginal, even if one concludes that it is insightful, though treated with a critical realist gloss. Nor is Bhaskar's dialectic foundational to Marxian dialectic. This is because Bhaskar's dialectical critical realism undoubtedly suffers from areas of damaging weakness (aside from its constipated academicism and its lofty level of conceptual abstraction), which are simply not to be found in Marxian dialectic. Further, it would itself be considerably enriched by virtue of a serious engagement with Engels' dialectical materialism, ${ }^{141}$ not least because Engels' materialist dialectic is in some important respects ontologically and methodologically consistent with it, whilst suffering from none of its damaging abstractionism.

Rather, the significance of Bhaskar's Dialectic is that it draws out, refines and systematises the conceptual logic of Marxian dialectic (at least in certain respects), and that it synthesises a formidable range of critical perspectives on Hegel, including Marx's, which are then organised and interpreted through the framework of Bhaskar's new and distinctive conceptual vocabulary. Yet there is some doubt over the adequacy of aspects of Bhaskar's critique of Hegel (in part because it is based on Marx), which unfortunately I cannot go into here. Nonetheless DCR is a decisive advance on CR, notwithstanding my critical comments, since a serious engagement with Hegelian and Marxian dialectic has considerably broadened and sharpened Bhaskar's critique in ways already described. But this should not distract us from recognising that the conceptual and analytical foundation of Dialectic is the path breaking Marxian critique of Hegel, or from grasping it as an extension and refinement of this critique, which is concerned with drawing out of its philosophical implications. Marxian dialectic is foundational to DCR, not vice versa.

\section{3) Problems and defects}

Enough said about some of the difficulties or ambiguities of Bhaskar's dialectic. What of the more substantial problems I alluded to earlier? There are five in particular, or so it seems to me. First, on the terrain of critical naturalism, Bhaskar's over-generalising concept of 'master-servant type social relations' is simply not adequate to the task of unravelling the complex relational determinations of the various axes of social power. What is the nature of the structured relationship between the various modes of domination, for example

141 Bhaskar actually finds much of value in Engels' reworking of Hegel's 'three laws', particularly his understanding of the 'negation of the negation' concept. Nonetheless rather more is required than the couple of pages Bhaskar devotes to Engels' diamat in Dialectic. Bhaskar 1993, pp. 150-2. 
those of class, gender, and ethnicity? Are the different modes autonomous factors of social power, or are they hierarchically structured in social systems by virtue of stratification and emergence? Which modes of domination, if any, have explanatory primacy in determining the overall socio-historical trajectory of social systems? Is Marx's base - superstructure model of structural causality in social systems of any practical analytic use in social theory?

Now getting questions of this kind right is indispensable to formulating an adequate social theory and emancipatory political practice. So too is obtaining a secure theoretical grasp of the nature and efficacy of agential properties and powers, of those of social structures, and of the interrelationship between them. After all, socialist practice has often been strung between the poles of political passivity or fatalism (influenced by the economic determinism of some forms of Marxism) and political adventurism (influenced by the humanist revolt against determinism and fatalism). Kautskyism and Third Worldism are classic examples of the opposing tendencies. ${ }^{142}$ Yet Bhaskar's exploration of 'power2' relations and social being more generally is far too condensed and abstract to deal with these sorts of questions and issues. Where he does refer to some of them, his treatment is rather insubstantial, consisting in assertion rather than theoretically and empirically informed argument.

A central claim of classical Marxism is, I think, the proposition that modes and relations of production, where these give rise to asymmetrical distributions of property, give rise to forms of domination other than class, such as stratification by gender and ethnicity. My argument ${ }^{143}$ is that Bhaskar's own CR concepts of stratification and emergence invest real theoretical content in this thesis, allowing a 'vertical' materialist explanation of non-economic modes of domination without 'explaining them away' or denying them autonomous causal powers or real-world effects. This allows Marx's base-superstructure model of society to be placed on a defensible conceptual footing.

A second important claim of historical materialism, which lends theoretical support to Marx's understanding of structural causality, is that class-based relations of production play the decisive role in determining the distribution of authoritative and allocative resources, and hence defining the vested interests and life chances of agents, in most historical social formations. I have shown too that this position is theoretically and empirically defensible. ${ }^{144}$ This thesis provides the hinge that connects up Marx's base-superstructure model with his materialist theory of history. This allows a 'class struggle model' of epochal structural or systemic transformations, supporting a tendential directionality in societal development from less advanced to more advanced socio-economic forms, such as that articulated by historical materialism. ${ }^{145}$ So Marx's 'primacy thesis' is certainly

\footnotetext{
${ }^{142}$ Molyneux 1985, pp. 34-40, 54-64.

${ }^{143}$ Creaven 2000c, pp. 1-38.

${ }^{144}$ Creaven 2000a, pp. 238-51.

${ }^{145}$ Creaven 2000b, pp. 23-46.
} 
heuristically defensible, I would say conceptually plausible, and it can be corroborated empirically by comparative and historical sociological research.

Now Bhaskar argues for neither of these positions. In fact, he seems to share the neo-Weberian view that society is comprised of a plurality of autonomous power centres or modes of domination, none of which can be legitimately attributed any kind of explanatory primacy over the others. If so, however, Bhaskar does not argue this position. Rather it is taken for granted. Instead he accuses Marx of being 'fixated on the wage-labour/capital relation at the expense of the totality of master-slave relations ... most obviously those of nationality, ethnicity, gender, religious affiliation, sexual orientation, age, health and bodily disabilities generally'. ${ }^{146}$ If Bhaskar is saying that the Marxist tradition has neglected generalised master-slave type social relations, he is simply mistaken. Marx himself sketched out the rudiments of a materialist understanding of racism, and racism has received much theoretical scrutiny since within Marxism. ${ }^{147}$ Engels attempted (more successfully than he is often given credit for) a materialist explanation of women's oppression, ${ }^{148}$ and much good work has been done to build on his analysis by a number of Marxists and non-Marxists up until the present day. ${ }^{149}$

But, of course, those who accuse Marxism of 'neglecting' modes of domination other than class and economy normally mean something other than neglect. What they actually mean is that Marxism is wrong to posit: (1) an explanatory reduction of modes of stratification generally to modes of production and class domination; and (2) that modes of class domination have explanatory primacy in shaping political agency and hence systemic dynamics in most historical contexts. This is the point at issue, which is obscured by the language of 'neglect' or 'fixation', and the tendency within anti-Marxist social theory to simply assume as a matter of commonsense that asserting either (1) or (2) is tantamount to economic determinism or 'greedy' class reductionism.

But I suppose that Bhaskar's claim can be read innocently as simply calling attention to the fact that not all power2 relations are class relations. To do so, however, seems a little naïve. After all, that this should be asserted so forcefully against Marx, in the context of the 'retreat from class' in the western academy and politics, and where the overwhelmingly dominant trend in social theory has

\footnotetext{
${ }^{146}$ Bhaskar 1993, p. 333.

${ }^{147}$ Callinicos (1992) outlines a particularly outstanding materialist explanation of racism, which builds on Marx's own insights. Other path-breaking texts include: Blackburn 1988; Fields 1990; Miles 1982; Castles and Kosak 1973; Williams 1961.

${ }^{148}$ Engels 1972.

${ }^{149}$ Harman (1994) offers an excellent account of the historical origins of women's subordination from a Marxist perspective, drawing upon a wide range of anthropological sources, and basing his account on the research findings of Marxist and non-Marxist anthropologists. German (1989) and Vogel (1983) develop penetrating Marxist analyses of women's oppression in contemporary capitalism.
} 
asserted that class has no priority at all on the strength of the reality of plural modes of domination, seems instructive as well as unfortunate. But Marx's position is a weakness only if relations of production/ structures of class domination do not have the kind of explanatory primacy in social systems specified by his theory. If Marxism is correct to specify the primacy of class relations and modes of production in constituting social systems, including other modes of domination, it is hardly a 'fixation' to concentrate analysis primarily on them. In Dialectic Bhaskar does not consider this possibility at all. Moreover, his claim that 'religious affiliation, ... age, health and bodily disabilities' are modes of master-slave type relationships in their own right, hence presumably equivalent to those of class, gender and race, is frankly implausible and deprives the concept of power2 relations of much of its critical edge. ${ }^{150}$

Second, Bhaskar's abstractionism seems especially damaging to his moral realism. Bhaskar argues that the task of politics and philosophy is to help bring about universal human freedom. The problem is that 'universal human flourishing' or the 'free development of all', though a laudable ideal to be aimed at, is probably unattainable as an absolute. Even in a genuinely socialist society, where power2 relations have been eradicated, individuals cannot enjoy absolute freedom in the sense of a total 'absence of absenting constraints' on their desires and wants. Even the most participatory and transparent forms of democracy, accompanied by the most radical redistributions of wealth, will not exclude specific policy-decisions that prioritise certain goals (and hence wants) at the expense of others, allocating resources here for this rather than there for that. The most that can be legitimately aspired to (and it's a big aspiration) is that the structured modes of domination that systematically subordinate the cultural and material needs of the global human population in the service of the vested interests of powerful elites can be dissolved, and replaced by a rational social order that combines socialised production and property ownership with participatory and representative

${ }^{150}$ This has not stopped some Marxists trying to claim Bhaskar's dialectical critical naturalism for historical materialism. In his Plato, Etc., Bhaskar does affirm that the Marxist thesis of the 'primacy of the mode of production and reproduction' is 'heuristically acceptable' Bhaskar 1994, pp. 101-2. Does this make him a historical materialist up at least until 1994? Probably not. There is no positive affirmation here of the primacy thesis or substantive analysis of how it might hold. Yet in Dialectic Bhaskar does appear to endorse the view that the capital-labour relation is the central dynamic of capitalism, and he does refer here to the global cultural domination of commodification. Again, some have taken this as a tacit endorsement on his part of the primacy thesis. But this is questionable. Both Weberians and postmodernists are often happy enough with the idea that the commodification of culture is a global master trend. A culture of commodification may well be a 'fateful power' of contemporary society, but this does not rule out the possibility that there are other 'fateful powers' of equal weight and significance besides. Since Bhaskar regards capitalism as just one nexus of power relations amongst a plurality of others, asserting the centrality of class relations here in the economic sphere is not the same thing as asserting their primacy in stratification systems per se. I conclude there is little that is distinctively Marxian about Bhaskar's substantive social theory. 
democracy in all substantive institutional spheres. This is Marx's communism. It is not paradise, not 'the ideal', nor devoid of conflict, but it is nonetheless an inspiring political and ethical goal, and one which is practically achievable.

Bhaskar's contrary view that eudaimonia denotes the unity of humankind in freedom and enlightenment does not seem radically different from Hegel's postulation of the identity of subject and object as the telos of history. This utopianism is pushed a further step forward in Bhaskar's From East to West. Here he argues that

man is essentially God (and therefore also essentially one, but also essentially unique); and that as such, he is essentially free and already enlightened, a freedom and enlightenment which is overlain by extraneous, heteronomous determinations which both (a) occlude and (b) qualify this essential fact... Man has to shed both the illusion that he is not essentially Godlike and free and the constraining heteronomous determinations (constituting the object world of illusion, duality and alienation) which that illusion grounds... The fundamental malaise then is self-alienation... To break free from it is to become what we most truly are... To change the world, man only has to realise himself ... To become free all we need to do is shed our illusions. These are the chains that bind us to the presence of the past. It is time to let go, to live life afresh. The hour for unconditional love has struck. ${ }^{151}$

The problems with this kind of abstract unhistorical moralism are threefold. First, it seems to dissolve the structural and cultural constraints which impede both unalienated consciousness and the construction of 'concrete utopias' as institutional realities. For these objective structures are now interpreted as being rooted in alienation and illusion, rather than as material causes of alienation and illusion in their own right. Second, given the stratified and open-ended nature of reality, and given that human knowledge is always culturally and socially constrained (and enabled) within determinate material circumstances, it follows that 'enlightenment' as a transcendental ideal is unrealisable. Our enlightenment will always be radically partial and incomplete.

Finally, unlike 'God', whose essence is 'spirit', humanity is the product of natural evolution at a certain level of its material development. This means that the essence of humankind is the specific nature of its materiality and those emergent properties that are rooted in this materiality. So our emancipatory potential is not absolute or totalising, but is bound within the structure of powers and liabilities of our human nature. The essential liabilities of our humanity include those we share with all living things (our dependence for sustenance on a material world that frustrates as well as facilitates our wants, the likelihood of serious illness and

${ }^{151}$ Bhaskar 2000, pp. ix, 51, 151-2. 
infirmity, the possibility of injury or disability, the certainty of death), plus others more specific to ourselves as people (the psychological insecurities that follow from absences in knowledge or understanding, the fear of mortality, loneliness, bereavement, unrequited love, the multitude of personal failings or imperfections that we all have and which sometimes dog our interactions with others and prevent us fully realising our potentials, and so on). The essential powers of our humanity consist not simply of 'consciousness' or 'spirit', but of the biologically based needs and interests common to human beings across space and time, those causal powers of sociality and labour that are specified by this embodied human constitution, and those subjective emergents of mind, self and rationality (plus their emergent properties of culture and language) that have arisen from the historical interface between these natural powers and tendencies and the objectworld mediated by practical agency.

So, contrary to Bhaskar, it is not the case that human beings are fundamentally free, but find themselves in chains. There is not a simple opposition between power and desire. Rather, humanity is essentially and simultaneously free and unfree. The task of realist ethics and politics should not be to mystify this existential reality, but to evaluate societies and systems of social relations in accordance with the respective relative degree of 'free flourishing of each and all' they allow their peoples. This is one of the tasks I set myself in my Marxism and Realism. ${ }^{152}$ This allows the ethical case for eudaimonia to be based on more substantive philosophical grounds, informed by the relevant human and biological sciences. Thus the historical necessity of socialism (in the moral sense) may be grasped on the basis of the greater correspondence of social forms to essential human interests it permits, as these are defined by the interface of biological and cultural needs mediated by the level of development of the material productive forces. Because socialism entails the abolition of power 2 relations, the real potential it offers humanity is that of the maximum possible autonomy and free flourishing of each as the condition for the free flourishing of all within the hiatus of freedom-within-unfreedom.

This concludes my critique of Bhaskar's moral realism. What of the other difficulties I alluded to? Second, and at a rather more mundane level, where Bhaskar ventures beyond Hegel to make a critique of classical materialist dialectic, this is one of the least successful aspects of his enterprise. A major bone of contention is certain aspects of Bhaskar's interpretation of the Marx-Hegel connection. For example, Bhaskar suggests that, under the influence of the closed Hegelian totality, 'neglect of external contradictions and more generally constraints ... has been a damaging feature of Marxian social theory in the Hegelian mode'. ${ }^{153}$ It is not clear what Bhaskar has in mind by his qualifying remark of 'in the Hegelian mode', since 'Hegelian Marxism' refers as much to the

\footnotetext{
${ }^{152}$ Creaven 2000a, pp. 85-9, 101-2, 279-80.

${ }^{153}$ Bhaskar 1998, p. 584.
} 
broader tradition of dialectical Marxist social theory (which is opposed to the mechanical materialist Marxist current of the Second International and Stalinism and some forms of Trotskyism) as it does to the humanist current especially characteristic of 'western Marxism', with which the term is sometimes associated. Bhaskar makes the same kind of point where he suggests that Marx, under the influence of Hegel, concentrated overmuch on internal contradictions.

Undoubtedly, Marx did focus on the internal (especially dialectical) contradictions of the capitalist mode of production, because his purpose was precisely demonstrating that these contradictions were essential or necessary to the logic of capital. This is exactly the strength of his critique of political economy. Yet Bhaskar himself demonstrates that 'Marx's critique of Hegel's philosophy of identity permits a plurality of dialectical configurations, topologies, perspectives and inscapes which .... [cannot] be captured by a single formula'. ${ }^{154} \mathrm{He}$ goes on to show how Marx's 'concept of contradiction is deployed to denote inter alia: (a) logical inconsistencies or other ... theoretical anomalies ...; (b) ... non-dialectical oppositions ...; (c) structural ... dialectical contradictions ... intrinsic to a particular social form; (d) geo-historically specific dialectical contradictions that bring into being a social form and/or crises in the course of its development which are then resolved in the process of transformation which they help to cause'. ${ }^{155}$ This suggests that Bhaskar's critique of Marxism cannot apply to Marx himself.

In fact, Bhaskar's discussion of the various kinds of contradiction that exist in reality (logical, internal, external, dialectical), is a genuinely interesting and ingenious aspect of his dialectic (though there is a question mark over its originality - some of it recalls 'Hegel's discussion of the various attitudes of thought to objectivity at the beginning of the Encyclopaedia Logic'), ${ }^{156}$ and a real enrichment of Marx's 'materialist diffraction of dialectic'. ${ }^{157}$ Nonetheless he does not establish the veracity of his initial critique of materialist dialectic in classical Marxian theory more generally as over-simple.

Dialectical materialism, as developed by Engels, Trotsky, Ilyenkov, and more contemporary figures (such as the left Darwinians), is radically antireductionist, rejecting the fantastic notion of a universal dialectic, and denying the relevance of attempting to apply the 'orthodox' triadic dialectic outside the realm of human cognition. Not only in Marx, but also implicit in Engels, is the idea that internal contradictions do not exhaust reality and are not the only mechanisms of structural transformation. Engels' Marxism, for instance, identifies logical contradictions (in the philosophy and politics of adversaries), and internal and external contradictions built into the structures of reality - ie. between structure and superstructure and different elements of the superstructure (external) and forces and relations of production and social classes (internal and transformative) -

\footnotetext{
${ }^{154}$ Bhaskar 1993, pp. 173-4.

155 Bhaskar 1993, p. 618.

${ }_{156}^{15}$ Again, I'm grateful to the anonymous reviewer of this paper for this insight.

${ }^{157}$ Bhaskar 1993, p. 98.
} 
both of which have explanatory significance. ${ }^{158}$ The fact that these are implicit rather than explicit does not mean that they are absent. I would say that a 'materialist diffraction of dialectic' is to be found in the work of all the major thinkers of classical Marxism. ${ }^{159}$

Bhaskar is also ill-informed, to offer a second example, in his sweeping assertion that the fundamental errors of both socialist politics and Marxian philosophy are ultimately explainable (or perhaps deeply embedded) in the conceptual weaknesses of their manner of appropriation or critique of Hegelian dialectic. For Bhaskar, Marx's rejection of Hegel's concept of 'preservative dialectical sublation, which incorporates the cancelled moments of the [historical] process within the final totality', leads 'to the failure ... to come to terms with the material ... presence of the past ${ }^{160}$ in the present. This is said to provide a philosophical explanation of the misguided attempt by the Stalinists to build 'socialism in one country', this evidencing the 'sinking back into a simple undifferentiated unity (reflecting the most primitive logic of Hegel's Being'. ${ }^{161}$ Thus the pathologies of 'state socialism' can 'be given Marxian credentials, however much Marx would have loathed the outcome'. ${ }^{16}$

For Bhaskar also, 'cognitive triumphalism', informed by the Hegelian notion of the closed totality, is the fundamental error of 'dialectical materialism':

Reality is a potentially infinite totality, of which we know something but not how much. This is not the least of my differences with Hegel, who, although a more subtle exponent of cognitive triumphalism ... nevertheless is a conduit directly connecting ... to Lenin and thence diamat and the erstwhile command economies of the omniscient party states. ${ }^{163}$

Yet these assertions (and that is really all they are) are under-theorised and remarkably weak. Bhaskar may well be right in his claim that the New Left requires better philosophy, but the idea that the politics of the statified ruling class of Stalinist Russia was even tenuously influenced by Hegelian dialectic or by the dialectical tradition of classical Marxism (for good or for ill) is frankly risible.

\footnotetext{
${ }^{158}$ Internal relations refer to elements that constitute a specific structure within a social system or social formation. Internal relations between elements of a structure are indispensable to it as a specific social form. A mode of production, for example, is comprised of internal relations (forces and relations of production, forms of circulation and distribution, etc.) that define it as such. External relations are those which pertain between the constituent structures of a wider society. So the relations of the economic system with the education system, though integral to the functioning of both and wider society, are external relations, since the defining relational elements and connections of each have no bearing on those of the other.

${ }^{159}$ Rees 1998, pp. 170-201, 262-89.

${ }^{160}$ Bhaskar 1993, p. 350.

${ }^{161}$ Bhaskar 1993, p. 333.

162 Bhaskar 1993, p. 350.

${ }^{163}$ Bhaskar 1998, p. 576.
} 
First, it is clear that Marx does not simply reject Hegel's 'preservative dialectical sublation', though he is rightly suspicious of the idea that all dialectical transitions of lower to higher social and intellectual forms must entail the preservation of elements of forms that have been transcended. In fact, Marx's view, central to his theory of history and socialist politics, that socialism is feasible only given the high level of development of the material productive forces engendered by capitalist development, is precisely a materialist restatement of this Hegelian idea. Far from representing continuity with Marxian ideas, Stalin's programme of 'socialism in one country' involved rewriting both Marxism and Leninism. ${ }^{164}$ Internationalism was replaced with nationalism to bolster the power of the newly emergent bureaucratic elite.

Thus Lenin and the Bolsheviks were unambiguous from the start that, if isolated in backward Russia, the revolution would degenerate and fail, precisely because the moment of the past in the present would prove ultimately decisive. Their political strategy for achieving socialism in Russia was predicated on the imminence of revolutions in the advanced capitalist societies, which their own actions would help ignite in the context of war- and recession-ravaged Europe, this allowing the massive transfer of material resources from West to East for purposes of socialist reconstruction. The failure of this strategy meant the revolution was subjected to relentless pressure by a combination of desperately unfavourable material circumstances. Chief among these was the devastation wreaked on the population and the productive forces by the fascistic counter-revolution and the foreign military interventions. This decimated the working class that made the revolution and which constituted the mainstay of soviet democracy, forced the regime to assume hyper-centralised command of society ('war communism') in order to defeat the counter-revolutionaries, and thus created the space for a new statified ruling class to assume the reigns of political and economic power through its control over the organs of party and state. ${ }^{165}$

Second, Bhaskar's view that Hegel's cognitive triumphalism' has cast its baneful shadow over dialectical materialism, is called into doubt by the simple fact that there are different forms of 'diamat', reductionist and non-reductionist. The absolutist, economic-determinist Stalinised versions of it stemmed not from philosophical errors, as Bhaskar seems to imply, but from the vested political interests of the elites that controlled the bureaucratised western communist parties and the former 'communist' states of Eastern Europe. Engels' dialectical conception of the 'interconnectedness of things', in contrast to fatalist or determinist versions, sees totality not as an absolute, but as a necessarily provisional or partial picture of nature, because reality is in constant movement

\footnotetext{
${ }^{164}$ Molyneux 1985, pp. 41-53.

${ }^{165}$ Callinicos 1991, pp. 15-40; Rees 1991, pp. 29-70.
} 
and change, which also functions as a necessary aspiration of scientific understanding or endeavour, even if never a fully attainable one. ${ }^{166}$

This insight of Engels has proven an extremely fertile one in providing guidance to certain forms of scientific analysis. For example, it has become central to the theoretical work of the so-called 'left Darwinians' in the modern biological and ecological sciences. Rose et al., ${ }^{167}$ for instance, show how an account of human society is richer and more complete, or aspires to a greater universality or more inclusive totality, if it strives to integrate the knowledge derived from a broad spectrum of the relevant sciences (social psychology, sociology, anthropology, evolutionary biology, etc.), than if it remains solely on the terrain of one or other of these sciences.

It is hard to dissent from Callinicos's view that Bhaskar is led into this unfortunate tendency of 'reading-off' complex social, political and economic outcomes from the 'original sin' of philosophical error as a consequence of the inflated status he would attribute to abstract philosophical reasoning of a transcendental nature in analysing and explaining the world. In his earlier work, Bhaskar attributed to philosophy the more modest role of 'under-labourer' and 'midwife' of science. ${ }^{168}$ Here philosophy, even though it gave guidance to science, was nonetheless open to revision and interrogation by the methods of thinking and practical resultants of the sciences, to the provisional knowledges these established about the world. Perhaps partly as a result of Bhaskar's 'mystical turn' (ie. his recent conversion to deism and the hokum of New Age spiritualism) represented by his From East to West, this more modest (and sensible) role assigned to philosophy has been increasingly undermined. The role and status of transcendental philosophical claims has been greatly expanded in Dialectic, allowing the 'logical' grounding of sociological and political arguments, which really need to be established on their own terrain. Philosophy, in its dialectical critical realist form, has become for Bhaskar 'foundational' to science.

This explains 'the proliferation of quick-kill arguments from a priori premises to conclusions embodying substantive and controversial generalisations about the world that is such a distressing feature of Dialectic' ${ }^{169}$ But, as Callinicos rightly says, 'there are grounds for thinking that a more consistent naturalism, which stressed more strongly than Bhaskar does the continuity between philosophy and the sciences and the former's dependence on the latter, could protect him from the extravagant claims for philosophy into which he is sometimes tempted, and provide a more secure basis for the many valid insights and fertile ideas this challenging and original philosopher has to offer'. ${ }^{170}$ This would draw Bhaskar's philosophy much closer to Engels' dialectical materialism,

\footnotetext{
${ }^{166}$ Rees 1994, pp. 73-4.

${ }^{167}$ Rose et al, 1984.

168 Bhaskar 1978.

${ }^{169}$ Callinicos 1994, p. 19.

${ }^{170}$ Callinicos 1994, p. 20.
} 
which is as much about philosophical generalisation from the methods and theories of the sciences as it is about providing methodological and theoretical guidance to practical scientific research.

Now, aside from Bhaskar's flawed understanding of the relationship between Hegel and the classical Marxist tradition, there are major problems with his substantive treatment of Marxian social theory. Bhaskar identifies a number of defects of Marx's historical materialism, ${ }^{171}$ which his own DCR system is said to have resolved. None of these are especially original or interesting. The first is that Marx treats class divisions as the primary mode of stratification in social systems. The second is that Marx endorses a linear 'stages' theory of socio-historical development. The third is that Marx sometimes tends to postulate 'endism' or 'teleologism', presenting communism as the necessary or logical terminus of the dialectic of history. The fourth is that Marx tends towards a kind of technological functionalism, stressing only the emancipatory role of the development of the productive forces, and ignoring the downside of technology under capitalism.

The fifth is that (apparently) Marx regarded nature anthropocentrically as simply the raw material of transformative social labour, and thus as something to be controlled or mastered by human beings, rather than as something upon which humans are dependent for their physical and mental well-being. The sixth is that Marx endorsed an (economic?) evolutionism, under the influence of Darwinian materialism. This presumably ties in with Marx's 'endism', technological functionalism, and 'stageism'. The seventh appears to be that Marx is guilty of downplaying the multiplicity of oppressions or antagonisms (modes of stratification) which have existed in most historical societies (I cannot be certain about this interpretation of his meaning given Bhaskar's opaque terminology). This weakness is presumably a function of Marx's prioritisation of class relations in social analysis.

At a later point in the book, Bhaskar revisits his critique of Marxism, where he suggests that Marx's account of transformative social change was pulled in opposite directions, between asserting a tendential determinism of historical outcomes by modes of production, and asserting the possibility of historical mutations, as determined by a plurality of non-economic processes. ${ }^{172}$ This seems a rather more qualified and cautious criticism of Marx and Marxism than the earlier ones of economism, endism and stageism. Nonetheless Bhaskar still attributes to Marx, on the strength of a single quote, a 'unilinear view of geohistory', from 'which spread the functionalist and evolutionary ... models characteristic of Marxism for most of this century'. ${ }^{173}$ 'This' Marx is said to be contradicted by the 'other' Marx, who denied a unilinear directional logic to

\footnotetext{
${ }^{171}$ Bhaskar 1993, pp. 93-5.

172 Bhaskar 1993, pp. 348-51

${ }^{173}$ Bhaskar 1993, p. 351.
} 
history, and who ridiculed attempts to portray historical materialism as postulating just such a unilinear historical pattern.

I will not dwell long on the defects of this 'shopping list' of Marxian errors, not least because I have already made the relevant disconfirming arguments both in this paper and at greater length elsewhere. Amazingly, Bhaskar's initial critique is compressed into just seven lines of text, and is so heavily jargonised it is difficult to be certain my above interpretation is a reasonable approximation of his argument. Assuming that it is, Marx deserves better treatment than this, particularly from a philosopher of the left. Obviously, it is very disappointing to see Bhaskar regurgitating what is to all intents and purposes the standard liberal critique of historical materialism, especially since most of this has been decisively undermined by a succession of left critics over the past twenty years. Bhaskar himself concedes that 'corresponding to each charge, one can find contrary evidence in his [Marx's] oeuvre'. ${ }^{174}$ Quite so. But this qualification does not go nearly far enough.

I have pointed out that there is in fact precious little textual evidence in Marx's voluminous writings that support the interpretations (of teleologism, economism, stageism, endism, anthropocentrism, etc.) that Bhaskar would foist on their author. I have argued that much of this (already sparse) textual evidence is of ambiguous meaning or significance. And I have pointed out that the overall theoretical logic of Marx's work (immature and mature) cuts overwhelmingly against the orthodox critique. All of this reveals the dangers of taking a handful of isolated passages out of context.

Bhaskar's charge of teleologism, which he aims at 'young Marx', is in any case a bit rich, given that he himself now appears committed to a form of historical teleology that seems stronger than the one hinted at by Marx even in his youthful Manuscripts. ${ }^{175}$ Yet Bhaskar is on to something where he takes Marx to task for asserting the primacy of class. Here Marx is indeed guilty as charged. Far from being a weakness of historical materialism, though, I have argued that Marx's insistence that class antagonisms and conflicts - as these are overdetermined by modes of production - have explanatory primacy in explaining the constitution and dynamics of social systems, is precisely its enduring strength. It certainly cannot be dismissed without reasoned argument by simply invoking the bogeyman of 'class/power2 one-dimensionality'. ${ }^{176}$ Here Bhaskar needs to do better.

I have now said enough about the weaknesses of Bhaskar's substantive critique of Marxism. I now wish to conclude by considering the question of the

\footnotetext{
${ }^{174}$ Bhaskar 1993, p. 351.

175 'Definitionally then, there is a conatus to deconstraint or freedom, in a depth dialectic and to the knowledge of the power2 relations constraining the satisfaction of wanted need. Absence will impose the geo-historical directionality that will usher in the truly human global society'. Bhaskar 1993, p. 169.

${ }^{176}$ Bhaskar 1993, p. 351.
} 
adequacy of some of Bhaskar's core dialectical concepts. Now Bhaskar is mistaken to argue, against Hegel, that dialectic is defensible only if the concept of 'unity' is subordinated to the concept of 'difference'. ${ }^{177}$ Bhaskar's argument in favour of this position is that Hegel's stress on unity eventually dissolves contradiction in the harmonious realm of the Absolute. On this interpretation, in a sense Hegel's contradictions aren't real, because they express partial or incomplete knowledge or rationality of a world that in essence is harmonious, though ignorant of its harmony, not of existential incompatibilities existing in their own right. But if Hegel is indeed guilty as charged, this error would seem more likely to follow from his teleological idealism than from his failure to explicitly prioritise difference over unity in an explanatory or ontological sense. After all, subordinating unity to difference could easily destroy totality (qua postmodern social theory), just as the reverse strategy dissolves conflict and contradiction (qua sociological functionalism). Since the two sides of being, difference and unity, are dialectically interpenetrated, it makes no sense to treat either as more or less significant than the other.

There are also problems with Bhaskar's fundamental treatment of dialectic as the 'absenting of absence'. For one thing, in Bhaskar's hands, this leads to the over-use and over-extension of dialectical causality, so much so it is in danger of being trivialised. Dialectic is simply far too elastic, this diminishing its explanatory power and theoretical interest, rather like the fate of the concept of power in Foucault's later work. Since virtually every event or action or state of affairs involves an absenting in some sense (unconsciousness absents consciousness, work absents leisure, drink absents thirst, food absents hunger, knowledge absents ignorance, standing up absents sitting down, spring absents winter, etc.), it seems that the concept is better reserved for a particular class of absences, namely real determinate negations, ie. those concepts that denote specific situations or states of absence without corresponding presence or positivity (illness as the absence of health, death as the absence of life, chaos as the absence of order, slavery as the absence of freedom, etc.). However, despite this criticism, Bhaskar's understanding of the dialectic of history as the absenting of constraining ills on freedom still stands. The 'logic of absence' is in this sense still the pulse of freedom.

177 This is paralleled by a certain slippage in Bhaskar's understanding of stratification and emergence in comparison to his earlier work. Here, instead of emergent strata being explained by those in which they are rooted, and hence determined by a specific pattern of complexity of interaction at the lower level, they are spontaneous innovations 'out of pre-existing material from which they could have been neither induced or deduced'. Bhaskar 1993, p. 49. Of course, to point out that higher order structures in society and elsewhere are 'determined' by underlying structures is not to resort to 'greedy reductionism'. 'Determination' should be grasped in terms of stratification, rootedness and emergence, meaning that, eg., physical mechanisms explain biological mechanisms, or economic mechanisms explain political mechanisms, without 'explaining them way' (they remain efficacious in their own right). 
Further, Bhaskar's ontological prioritising of absence over presence seems problematic. There are two difficulties here. First, Bhaskar does not demonstrate satisfactorily that non-being should be prioritised over being. Bhaskar claims that 'if there was a unique beginning to everything it could only be from nothing by an act of radical autogenesis' ${ }^{178}$ This does not advance his case at all, however, since speculative 'ifs' and 'buts' don't add up to an argument, and 'something out of nothing' is obviously a violation of the law of non-contradiction. ${ }^{179}$ Precisely because absence (in our world at least) can only be defined in relation to presence, and of course vice versa, and precisely because it is impossible to attribute any rational meaning to 'something out of nothing', this is insufficient to establish Bhaskar's view that non-being is foundational to being.

The problem here is that Bhaskar's generally good arguments in defence of the idea that negativity or absence is ontologically real, ${ }^{180}$ and thus his arguments against the doctrine of ontological monovalence, are often treated as adequate to the job of demonstrating his stronger claim that negativity (determinate non-being) is ontologically basic or prior to positivity (determinate being). Bhaskar is probably correct to claim that 'the identification of a positive existent is a human act', thus involving 'the absenting of a pre-existing state of affairs', this constituting transcendental deduction of the category of absence'. ${ }^{181} \mathrm{He}$ is also on to something where he argues that only 'in a state of eternal all-pervasive monism would the category of absence not be necessary for the deduction of coherent concepts of space and time'. ${ }^{182}$ But all of this seems inconclusive on the deeper issue of whether either being or non-being (or neither one nor the other) should be regarded as ontologically basic.

Bhaskar asserts that positive presence is but the surface ripple on an ocean of negativity. But how can this be ontologically justified? Bhaskar argues that 'a world without voids (absences)', that is, 'a ... material object world ... of condensely compacting particles ... would be a world in which nothing could move or occur, as it presupposes an impossible conjunction of atomicity, rigidity and immediacy'. ${ }^{183}$ This takes him to what he believes is a decisive fourth argument in defence of his position. 'If a totally positive material object world - a packed world without absences - is impossible, there is no a priori reason to exclude the opposite - namely a total void, literally nothing. ${ }^{184}$ So absence is

\footnotetext{
${ }^{178}$ Bhaskar 1993, p. 46.

${ }^{179}$ In fairness to Bhaskar, he does not appear to endorse creation ex nihilo in Dialectic. But this makes this argument of Bhaskar's for the possibility of negativity being prior or foundational to positivity a rather odd one. However, in From East to West, Bhaskar does appear to endorse creation ex nihilo.

${ }^{180}$ Bhaskar 1993, pp. 44-7.

${ }^{181}$ Bhaskar 1993, p. 44.

182 Bhaskar 1993, p. 44.

${ }_{183}$ Bhaskar 1993, pp. 45-6.

${ }^{184}$ Bhaskar 1993, p. 46.
} 
ontologically prior to presence, for Bhaskar, because a material pluriverse without voids is logically inconceivable, whereas a pluriverse of determinate non-being or negativity is at least possible.

Here Bhaskar is on to something. But this is still indecisive. For sure, negativity or non-being is conceivable without being or positive presence, and not vice versa, but this has no bearing on the issue of whether in reality the first is prior or foundational to the second or whether the two have co-existed through eternity as interdependent realities. To assume as much is precisely to make the error of logicising being and non-being, which Bhaskar accuses Hegel of. But, since the only reality our science and philosophy can speak meaningfully about is our world, in which presence and absence are on a par with one another and necessarily interdependent, this seems a good enough reason to treat Bhaskar's transcendental deduction of the ontological primacy of negativity with suspicion.

But, in fact, it is possible to draw a more radical conclusion against Bhaskar, though perhaps not a decisive one. For a tentative argument, this one based not on transcendental methods but rather on the knowledge provided by the contemporary physical sciences, can be made in support of the thesis that being is ontologically basic to non-being. Certainly, despite Bhaskar's claim that there must be empty space between materialities to allow the possibility of matter-inmotion, and so development, emergence, etc., it has to be admitted that this by no means follows, not if we grasp materiality as possessing physical and non-physical attributes or dimensions, and the inherent capacity to transform itself from one to the other.

Modern physics does appear to provide some kind of warranty for this view:

Even the notion of the vacuum, empty space, has now been shown to be mistaken on closer investigation. Rather the vacuum seems to be a bubbling sea in which particles, packets of matter and energy, continually froth in and out of existence... Moreover, all the known 'particles' and 'forces' of matter are simply different and transient manifestations of the same underlying essence (which most scientists would today call energy)... This is not just speculation. This process plays a key role, for example, in the spontaneous emission of light by some atoms. The general picture emerging from modern physics is that change, continual process, interaction and transformation are a fundamental property of matter, and of the space that can no longer be seen as separate from it. ${ }^{185}$

This seems to suggest that absolute determinate absence, in the ontological sense, is questionable. At the 'rock bottom' physical level of our universe, instead of reality consisting of being and non-being, it is rather comprised of the continual transformation or transmission of the various 'forces' and 'particles' of material

${ }^{185}$ McGarr 1994, p. 166. 
being into each other. ${ }^{186}$ One virtue of this reversal of Bhaskar's argument is that it overcomes the difficulty of squaring dialectical causality (ie. dialectic as the logic of stratification and emergence) with the notion that 'rock-bottom' reality is simply existential disorder, randomness, potentia, pure dispositionality, structurelessness, etc. ${ }^{187}$ Since non-being has no causal powers (these pertaining only to relations between things, ie. structures), and since dialectical processes of absenting absence (and hence of evolutionary emergence) are energised by virtue of structures, it is difficult to see how a world of positive being could have emerged from a state of pure negativity or void. In short, the logic of dialectic itself does not seem consistent with Bhaskar's ontological prioritisation of absence over presence.

Another problem with Bhaskar's ontological prioritising of absence has been identified by Callinicos. 'If, as Bhaskar claims, '[n]on-being is a condition of possibility of being', why is there a tendency to eliminate it? Whence the impulse to absent absence, if absence is ontologically prior to presence?'. ${ }^{188}$ As Callinicos rightly observes, the only substantial answer Bhaskar gives to this question is specific to the human and social world. The 'absenting of absence' is conceived by Bhaskar as 'absenting most notably of constraints on desires, wants, needs and interests'. ${ }^{189}$ Thus Bhaskar argues that absenting absence is energised by the 'inner urge that flows universally from the logic of elemental desire (lack, need, want or desire). It manifests itself wherever power2 relations hold sway'. ${ }^{190}$ Yet, '[i]n general, Bhaskar seems to regard the dialectic as operative in nature as well as in society'. ${ }^{191}$ For Bhaskar 'there is nothing anthropomorphic about the dialectic presented here'. ${ }^{192}$ This being the case, the problem arises as to how and why the dialectical process unfolds outside the human-social world by virtue of the absenting of absence. Bhaskar provides no satisfactory answer to this question.

Instead Bhaskar's explanation of the pulse of dialectic outside the human and social worlds consists simply of asserting the uncontroversial fact that change and development precisely is the process of absenting or negating a stratum, object, or state of affairs. To negate or absent something is by definition to act causally in the world and thus to bring about a transformative change in the world. Dialectic is thus the dynamic interplay of causal power and contradiction. But this seems to be a mere description of dialectical causality rather than an explanation

\footnotetext{
186 This argument should not be taken to mean I dissent from Bhaskar's view that absence is ontologically real. This is the rational core of his dialectic. Rather, I am saying that Bhaskar's ontological prioritisation of absence over presence is at least questionable and problematic.

${ }^{187}$ Porpora 2000.

${ }^{188}$ Callinicos 1994, p. 12.

${ }^{189}$ Bhaskar 1993, p. 175.

${ }^{190}$ Bhaskar 1993, p. 229.

${ }^{191}$ Callinicos 1994, p. 12.

192 Bhaskar 1993, p. 304.
} 
of how or why it unfolds at different levels of the cosmos. ${ }^{193}$ The dialectic here has no genuinely causal status, because no explanation is given of why there exists this drive or imperative to absent absence in unreflective inorganic nature, or how this dialectical impulse of absenting absence is translated into mechanisms of transformative change at different strata of nature.

Nor do I think that a satisfactory answer can be given. Certainly, the dialectic conceived in this way functions as an understanding of the dialectics of consciousness and life. In the former case, conceptual progress is indeed a function of the rational drive to overcome 'gaps' in understanding or knowledge, and this process is ultimately energised by the desire of human beings to maximise their freedoms. In the latter case, it is at least conceivable that the essence of dialectic consists in its parcelling out of constraints on freedom or autonomy (positivity as the converse of negativity). For it is plausible to see organisms as engaged in a struggle against their own absenting or to absent those forces or negations that restrict or constrain their life-chances.

Thus the 'absenting of absenting ills' appears here as a genuinely causal mechanism or logic of explanation. But this kind of explanatory logic or mode of causality allows little purchase on the unreflective dialectic of inorganic nature. This knows nothing of rationality, desire, freedom, need, and authors no struggle against lack. Indeed, as I have tried to show elsewhere, ${ }^{194}$ Engels' 'laws of the dialectic', in particular his understanding of emergence and stratification as functions of determinate negations specific to particular strata and objects, offers far more grip on the dynamics of change in natural systems than this abstract universalising formulation of Bhaskar's.

\section{Conclusion}

Rather than summarise the preceding, I will finish with a few substantive conclusions on the question of the contemporary significance and status of Bhaskar's Dialectic and the CR system upon which it is based. First, despite its problems and errors, Bhaskar's dialectic is unquestionably the most significant statement of dialectical realist philosophy to emerge outside classical Marxism. The scope and ambition of Bhaskar's project is hugely impressive. Not only is DCR the genuine enrichment and progressive radicalisation of CR that Bhaskar claims for it, it is furthermore the most comprehensive critical review of classical dialectical philosophy (even if some of this misses the target). Dialectic is significant because it is a powerful challenge to opponents of dialectic both inside and outside the CR camp, and an important restatement of the relevance of

${ }^{194}$ Creaven 2001, pp. 131-54. 
Marxian dialectic and legitimate systematic specification of it (for reasons discussed in this paper).

The main strengths of Dialectic can be summarised as follows:

1) Stratification and emergence. These dialectically reworked concepts allow a precise theoretical specification of the central category of Marxian dialectic - unity-in-difference or differentiated totality. Now the ghost of reductionism (whether of wholes to their parts or parts to their wholes) has been decisively dispelled.

2) The non-preservative sublation of Hegelian dialectic. Though starting off from Marx's critique of Hegel, Bhaskar assembles the most systematic and comprehensive review of Hegel's system. Though much of this is unoriginal, and some of the critique of Hegel is perhaps misplaced, Bhaskar still impressively synthesises a wide range of critical commentaries on Hegelian dialectic with his CR and DCR concepts, this supporting a materialist diffraction of dialectic broadly consistent with Marx's dialectic.

3) Negativity and the logic of absence. This is the engine of Bhaskar's dialectic, and the conceptual centrepiece of the book. Although there are problems with Bhaskar's view that all change is a function of absenting absence, and with his claim that 'negativity wins' (in the sense of enjoying ontological priority over positive being), Bhaskar nonetheless demonstrates that negativity and absence are as ontologically real as positivity and presence. His argument is a brilliant demolition of ontological monovalence.

4) Modes of negation and contradiction. A systematic specification of the nature of dialectic. Though much of Bhaskar's argument recalls Hegel's own insights, there is value in Bhaskar's translation of these into his DCR mode. This seems to me to have practical analytical use in social theory and research in unravelling the nature, limits and possibilities of systemic change.

5) Eudaimonia and socio-historical development. A most welcome development of Bhaskar's critical naturalism. Against the overwhelmingly dominant current in contemporary social theory, which regards socio-historical processes as simply indeterminate, dialectical critical naturalism postulates a tendential directionality or 'directional impulse' in socio-historical development towards human emancipation. Despite Bhaskar's critique of Marx's evolutionism, this is undoubtedly a 
form of evolutionism, and broadly consistent (in this specific emancipatory sense) with historical materialism.

Second, despite its considerable merits, Bhaskar's Dialectic cannot be seen as underwriting Marxian dialectic, or as a sublation of Marxian dialectic in the sense of providing historical materialism with new dialectical concepts which simultaneously preserve yet supersede the old (and which are therefore indispensable to it), if indeed this is its intention, which is far from certain. Dialectic leans rather too heavily on materialist dialectic (including Marx's critique of Hegel) for this to be a plausible interpretation of its function. Nor, indeed, can it legitimately function as an alternative to the dialectical materialism pioneered by Engels on the terrain of philosophy proper, since I have argued that this form of diamat shares with the DCR ontology at least some of its strengths and fewer of its weaknesses.

This being the case, it seems that the best way forward for dialectical philosophy and social theory is attempting a synthesis of the best elements of DCR and materialist dialectic: from Bhaskar, the dialectically reworked concepts of depth realism (especially stratification and emergence); from Marxism the philosophical dialectical framework within which these ontological concepts and Bhaskar's insights into dialectic can be incorporated. Bhaskar thus far has not fully accomplished this objective.

Finally, and I would say inevitably for a work of this scope and ambition, Bhaskar's fledgling DCR system introduced here is not without ambiguities, difficulties and (a handful of) more substantial defects. Though many of the ambiguities and difficulties will doubtless be resolved when Bhaskar pursues and clarifies many of the themes and issues he has only touched on in Dialectic (ie. in his forthcoming Dialectical Social Theory), the more substantial problems I have identified will require conceptual revision to overcome.

These include: (1) Bhaskar's thesis that non-being is basic to being; (2) his attempt to grasp dialectic generally (ie. outside the domains of the organic and human-social worlds) as the impulse or drive to absent constraints on constraining ills (in fact, the application of Bhaskar's dialectic is specific to society, life and consciousness, and extends no further; (3) the abstract utopianism and idealism of his moral realism; (4) his substantive critique of Marxian historical materialism and aspects of materialist dialectic; and (5) his tendency to locate sub-optimal substantive societal and historical outcomes (eg. Stalinism) in the 'original sin' of philosophical error.

Excising these weaknesses will not subvert the substance of Bhaskar's DCR philosophy, which is on balance an impressive accomplishment, but will strengthen it. Of course, whether Bhaskar is able to build on his 'materialist diffraction of dialectic' will depend on his ending his recent unfortunate flirtation with irrealist dialectics (idealism, godism, spiritualism, etc.). It is to be hoped that he does so. So too that he remedies his unfortunate tendency towards academicism 
and scholasticism, which has marred his recent work, and which has unfortunately blunted the critical and emancipatory edge of Dialectic.

\section{References}

Archer, Margaret 2000, Being Human: The Problem of Agency, Cambridge: Cambridge University Press.

Archer, Margaret 1995, Realist Social Theory: The Morphogenetic Approach, Cambridge: Cambridge University Press.

Archer, Margaret, Bhaskar, Roy, Collier, Andrew, Lawson, Tony, and Norrie, Alan (eds.) 1998, Critical Realism: Essential Readings, London and New York: Routledge.

Arthur, Christopher J. 1986, Dialectics of Labour: Marx and his Relation to Hegel, Oxford: Blackwell.

Bhaskar, Roy 2000, From East to West: Odyssey of a Soul, London: Verso.

Bhaskar, Roy 1998, 'Critical Realism and Dialectic' in Critical Realism: Essential Readings, edited by Margaret Archer et al, London and New York: Routledge.

Bhaskar, Roy 1994, Plato, Etcetera: The Problems of Philosophy and their Resolution, London: Verso.

Bhaskar, Roy 1993, Dialectic: The Pulse of Freedom, London: Verso.

Bhaskar, Roy 1989a, The Possibility of Naturalism, Second Edition, Hemel Hempstead: Harvester Wheatsheaf.

Bhaskar, Roy 1989b, Reclaiming Reality, London: Verso.

Bhaskar, Roy 1978, A Realist Theory of Science, Second Edition, Brighton: Harvester Press.

Bhaskar, Roy and Alan Norrie 1998, 'Dialectic and Dialectical Critical Realism' in Critical Realism: Essential Readings, London and New York: Routledge.

Blackburn, Robin 1988, The Overthrow of Colonial Slavery: 1776-1848, London: Verso.

Bourdieu, Pierre 1998, Acts of Resistance: Against the New Myths of Our Time, Cambridge: Polity Press.

Brown, Andrew 2001, 'Developing Realistic Philosophy: From Critical Realism to Materialist Dialectics' in Critical Realism and Marxism, edited by Andrew Brown and Steve Fleetwood London and New York. Routledge.

Brown, Andrew, Steve Fleetwood and John Roberts (eds) 2001, Critical Realism and Marxism, London and New York. Routledge.

Callinicos, Alex 1998, 'The secret of the dialectic', International Socialism, 2: 78, 93-104.

Callinicos, Alex 1994, 'Critical Realism and Beyond: Roy Bhaskar's Dialectic' Working Paper no. 7, Department of Politics, University of York (unpublished). 
Callinicos, Alex 1992, Race and Class, London: Bookmarks.

Callinicos, Alex 1991, The Revenge of History: Marxism and the East European Revolutions, Cambridge: Polity Press.

Castles, Stephen and Kosack, Godula 1973, Immigrant Workers and Class Structure in Western Europe, Oxford: Oxford University Press.

Creaven, Sean 2000a, Marxism and Realism: a materialistic application of realism in the social sciences, London and New York: Routledge.

Creaven, Sean 2000b, 'Marx's theory of history: a realist reconstruction' Department of Sociology, University of Warwick (unpublished), 1-46.

Creaven, Sean 2000c, 'Marxism, stratification and power: a critique of pluralist sociology', Department of Sociology, University of Warwick (unpublished), $1-38$.

Creaven, Sean 2001, 'Materialism, realism and dialectic' in Critical Realism and Marxism, edited by Andrew Brown and Steve Fleetwood London and New York. Routledge.

Danaher, Kevin and Burbach, Roger (eds) 2000, Globalise This! The Battle against the World Trade Organisation and Corporate Rule, Monroe: Maine.

Engels, Frederick 1982, The Dialectics of Nature, Moscow: Progress Publishers.

Engels, Frederick 1975, Selected Correspondence, Moscow: Progress Publishers.

Engels, Frederick 1972, The Origins of the Family, Private Property and the State, London: Lawrence and Wishart.

Fields, Barbara J 1990, 'Slavery, Ideology and Race in the United States of America' in New Left Review, 181, 95-107

George, Susan 1994, A Fate Worse than Debt, Harmondsworth: Penguin.

German, Lindsey 1989, Sex, Class and Socialism, London: Bookmarks.

Giddens, Anthony 1984, The Constitution of Society: Outline of the Theory of Structuration, Cambridge: Polity Press.

Giddens, Anthony 1994, Beyond Left and Right, Cambridge: Polity Press.

Giddens, Anthony 1979, Central Problems in Social Theory, London: Macmillan.

Hegel, George W.F.1977, The Phenomenology of Spirit, Oxford: Oxford University Press.

Ilyenkov, Evald V 1997, 'The Question of the Identity of Thought and Being in Pre-Marxist Philosophy'in Russian Studies in Philosophy, vol. 36, no. 1.

Ilyenkov, Evald V 1977, Dialectical Logic: Essays on its Theory and History, Moscow: Progress Publishers.

Klein, Naomi,1990, No Logo, London: Flamingo.

Lenin, Vladimir I. 1972, Collected Works, vol. 38, Moscow: Progress Publishers.

Lewontin, Richard C. and Levins, Richard 1986, The Dialectical Biologist. Cambridge MA: Harvard University Press.

Marx, Karl 1976, Capital, vol. 1, Harmondsworth: Penguin.

Marx, Karl 1975, The Poverty of Philosophy, Moscow: Progress Publishers.

Marx, Karl 1973, Grundrisse, Harmondsworth: Penguin. 
Marx, Karl 1971, Theories of Surplus Value, vol. 3, Moscow: Progress Publishers.

Marx, Karl 1970, A Contribution to the Critique of Political Economy, London: Lawrence and Wishart.

Marx, Karl 1967, Capital, vol. 3, New York: International Publishers.

Marx, Karl 1959, The Economic and Philosophic Manuscripts of 1844, London: Lawrence and Wishart.

Marx, Karl 1934, Letters to Dr. Kugelmann, Moscow: Progress Publishers.

Marx, Karl and Engels, Frederick 1975, Collected Works, vol. 4, London: Lawrence and Wishart.

Marx, Karl and Engels, Frederick 1975, Collected Works, vol. 6, London: Lawrence and Wishart.

Marx, Karl and Engels, Frederick 1970, The German Ideology, London: Lawrence and Wishart.

Marx, Karl and Engels, Frederick 1967, The Communist Manifesto, Harmondsworth: Penguin.

McGarr, Paul 1994, 'Engels and natural science', International Socialism, 2:65, 143-76.

Miles, Robert 1982, Racism and Migrant Labour, London: Routledge and Kegan Paul.

Molyneux, John 1995, 'Is Marxism deterministic?', International Socialism, 2:68, $37-74$.

Molyneux, John 1985, What is the Real Marxist Tradition? London: Bookmarks.

Porpora, Doug 2000, 'Quantum Reality as Unrealised Possibility' in Alethia, vol. 3 , no. 2, 34-9.

Rees, John 1998, The Algebra of Revolution: The Dialectic and the Classical Marxist Tradition, London and New York: Routledge.

Rees, John 1994, 'Engels' Marxism' in J. Rees, ed. The Revolutionary Ideas of Frederick Engels, London: Bookmarks.

Rees, John 1991, 'In Defence of October' in International Socialism, 2:52, 3-82.

Rose, Steven, Lewontin, Richard C. and Kamin, Leon. J.1984, Not in Our Genes: Biology, Ideology and Human Nature, Harmondsworth: Penguin.

Sayers, Sean 1998, Marxism and Human Nature, London and New York: Routledge.

Sayers, Sean 1996, 'Engels and Materialism' in C.J. Arthur Engels Today. London: Macmillan.

Sheenan, Helena 1993, Marxism and the Philosophy of Science, Atlantic Highlands NJ: Humanities Press.

Smith, Tony 2000, 'The Relevance of Systematic Dialectics to Marxian Thought: A Reply to Rosenthal' in Historical Materialism, vol. 4, 51-65.

Smith, Tony 1993a, 'Marx's Capital and Hegelian Dialectical Logic' in F. Mosley and M. Campbell 1997, New Investigations of Marx's Method. Atlantic Highlands NJ: Humanities Press. 
Smith, Tony 1993b, Dialectical Social Theory and its Critics: from Hegel to Analytical Marxism and Postmodernism, Albany: State University of New York Press.

Smith, Tony 1990, The Logic of Marx's Capital: Replies to Hegelian Criticisms, Albany: State University of New York Press.

Trotsky, Leon 1986, Philosophical Notebooks 1933-35: Writings on Lenin, Dialectics and Evolutionism, New York: Columbia University Press.

Trotsky, Leon 1973a, In Defence of Marxism, London: New Park Publications.

Trotsky, Leon 1973b, The Writings of Leon Trotsky 1939-40, New York: Pathfinder Press.

Williams, Eric 1961, Capitalism and Slavery. London: Deutsch. 